\title{
Black carbon or brown carbon? The nature of light-absorbing carbonaceous aerosols
}

\author{
M. O. Andreae ${ }^{1}$ and A. Gelencsér ${ }^{2}$ \\ ${ }^{1}$ Max Planck Institute for Chemistry, Biogeochemistry Department, P.O. Box 3060, 55020 Mainz, Germany \\ ${ }^{2}$ Air Chemistry Group of the Hungarian Academy of Sciences, University of Veszprém, P.O. Box 158, H-8201 Veszprém, \\ Hungary
}

Received: 13 January 2006 - Published in Atmos. Chem. Phys. Discuss.: 4 May 2006

Revised: 24 July 2006 - Accepted: 24 July 2006 - Published: 28 July 2006

\begin{abstract}
Although the definition and measurement techniques for atmospheric "black carbon" ("BC") or "elemental carbon" ("EC") have long been subjects of scientific controversy, the recent discovery of light-absorbing carbon that is not black ("brown carbon, $\mathrm{C}_{\text {brown }}$ ") makes it imperative to reassess and redefine the components that make up lightabsorbing carbonaceous matter (LAC) in the atmosphere. Evidence for the atmospheric presence of $\mathrm{C}_{\text {brown }}$ comes from (1) spectral aerosol light absorption measurements near specific combustion sources, (2) observations of spectral properties of water extracts of continental aerosol, (3) laboratory studies indicating the formation of light-absorbing organic matter in the atmosphere, and (4) indirectly from the chemical analogy of aerosol species to colored natural humic substances. We show that brown carbon may severely bias measurements of "BC" and "EC" over vast parts of the troposphere, especially those strongly polluted by biomass burning, where the mass concentration of $\mathrm{C}_{\text {brown }}$ is high relative to that of soot carbon. Chemical measurements to determine "EC" are biased by the refractory nature of $\mathrm{C}_{\text {brown }}$ as well as by complex matrix interferences. Optical measurements of "BC" suffer from a number of problems: (1) many of the presently used instruments introduce a substantial bias into the determination of aerosol light absorption, (2) there is no unique conversion factor between light absorption and "EC" or "BC" concentration in ambient aerosols, and (3) the difference in spectral properties between the different types of LAC, as well as the chemical complexity of $\mathrm{C}_{\text {brown }}$, lead to several conceptual as well as practical complications. We also suggest that due to the sharply increasing absorption of $\mathrm{C}_{\text {brown }}$ towards the UV, single-wavelength light absorption measurements may not be adequate for the assessment of ab-
\end{abstract}

Correspondence to: M. O. Andreae

(andreae@mpch-mainz.mpg.de) sorption of solar radiation in the troposphere. We discuss the possible consequences of these effects for our understanding of tropospheric processes, including their influence on UVirradiance, atmospheric photochemistry and radiative transfer in clouds.

\section{Background}

Soot, the black material in smoke from wood and coal fires, has been seen as the archetypical air pollutant throughout history (Brimblecombe, 1987). Its presence in the atmosphere even at the remotest locations was discovered in the 1970s and 1980s (Levin and Lindberg, 1979; Heintzenberg, 1982; Andreae, 1983), and the early studies on the environmental cycle of "black carbon" (BC) were summarized in the monograph Black Carbon in the Environment by E. D. Goldberg (1985). A recent review on the geochemistry of "black carbon" in the environment has been provided by Masiello (2004). In this section, we present background information on the evolution of the study of "black carbon" and introduce the relevant concepts and terms. We also provide a set of definitions based on this discussion, which we will use in the rest of the paper, and which we propose for general use.

In recent years, scientific attention has shifted from the role of black carbon as a pollutant to its importance as a driver of global warming (Andreae, 1995; Hansen et al., 1998; Hansen and Nazarenko, 2004; Hansen et al., 2005; Ramanathan et al., 2005). Some model calculations suggest that its climate forcing may rival that of methane, and that the present-day global warming due to black carbon may be as much as $0.3-0.4^{\circ} \mathrm{C}$ (Jacobson, 2004; Chung and Seinfeld, 2005), while others estimate a smaller climate effect from this substance (Jones et al., 2005). Consequently, there is

Published by Copernicus GmbH on behalf of the European Geosciences Union. 
substantial controversy about the benefits of reducing "BC" as a strategy to mitigate global warming (Hansen et al., 2000; Jacobson, 2002; Bond and Sun, 2005). Because the climate effects of "BC" aerosol depend strongly on its physical and chemical properties, as well as on its residence time and distribution in the atmosphere (Jacobson, 2001), a thorough understanding of these properties and accurate techniques for the determination of "BC" in the atmosphere are deemed essential.

The terminology in this field draws upon a variety of definitions that are based on source processes, morphological characteristics, chemical composition and optical properties. Since these definitions are usually not congruent, the terminology has evolved to be confusing, complex and contradictory. We give here a set of definitions for the way the various terms referring to atmospheric carbon will be used in this paper. These definitions will be explained and discussed in more detail later in the paper.

"Soot": A black, blackish or brown substance formed by combustion, present in the atmosphere as fine particles ("soot particles"), or adhering to the sides of the chimney or pipe conveying the smoke.

"Soot carbon" $\left(\mathrm{C}_{\text {soot }}\right)$ : Carbon particles with the morphological and chemical properties typical of soot particles from combustion: Aggregates of spherules made of graphene layers, consisting almost purely of carbon, with minor amounts of bound heteroelements, especially hydrogen and oxygen. This definition does not include the organic substances (oils, etc.) frequently present in or on combustion particles.

"Brown carbon" $\left(\mathrm{C}_{\text {brown }}\right)$ : Light-absorbing organic matter (other than $\mathrm{C}_{\mathrm{soot}}$ ) in atmospheric aerosols of various origins, e.g., soil humics, humic-like substances (HULIS), tarry materials from combustion, bioaerosols, etc.

Light-absorbing carbon (LAC): General term for lightabsorbing carbonaceous substances in atmospheric aerosol, includes $\mathrm{C}_{\text {soot }}$ and $\mathrm{C}_{\text {brown }}$. Note that this term is used here in a somewhat different way than by Bond and Bergstrom (2006), who define it to mean the same as our term $C_{\text {soot}}$.

"Elemental carbon" ("EC"): Used here (always in quotes) in the sense that is conventionally and carelessly used in the literature, usually implying a near-elemental soot-carbonlike composition, and in most cases referring to the fraction of carbon that is oxidized in combustion analysis above a certain temperature threshold, and only in the presence of an oxygen-containing atmosphere.

"Apparent elemental carbon" $\left(\mathrm{EC}_{\mathrm{a}}\right)$ : Operationally defined as the fraction of carbon that is oxidized above a certain temperature threshold in the presence of an oxygencontaining atmosphere. May be corrected for charring, depending on the technique used.

"Black carbon" ("BC"): Used here (always in quotes) in the sense that is conventionally and carelessly used in the literature, generally implied to have optical properties and composition similar to soot carbon. In the climate-science community this is the most commonly used term, without consideration of its unclear definition. Also commonly used for the result of a LAC measurement by an optical absorption technique.

"Equivalent black carbon" $\left(\mathrm{BC}_{\mathrm{e}}\right)$ : Operationally defined as the amount of strongly light-absorbing carbon with the approximate optical properties of $\mathrm{C}_{\text {soot }}$ that would give the same signal in an optical instrument (e.g., the aethalometer) as the sample.

In the literature, "black carbon" or "soot carbon" are often used synonymously for the major light-absorbing component of combustion aerosols (aka "soot"). Soot carbon has been identified as an impure form of near-elemental carbon with a graphite-like structure, which is formed in flaming combustion and in internal combustion engines (White and Germer, 1941; Grisdale, 1953; Medalia and Rivin, 1982; Bockhorn, 1994). In fact, soot particles are one of the few particle types that can be readily recognized under the scanning or transmission electron microscope by their special morphology (Oberlin, 1989). Primary soot particles, $10-50 \mathrm{~nm}$ spherules, do not exist by themselves in ambient air-instead they cluster together immediately after their formation in a flame to form aggregates, which are their most stable form (Wentzel et al., 2003). In fresh smoke, these clusters tend to form open structures, which are then transformed by aging processes, including the uptake of water, into more closely packed particle types (Colbeck et al., 1990; Weingartner et al., 1997; Ruellan et al., 1999; Abel et al., 2003; Onischuk et al., 2003). However, soot particles associated with the smoldering stage of biomass combustion usually are present as much larger spherical and compacted aggregates that seem to be more resistant to atmospheric aging processes (Martins et al., 1998b).

The initial chemical composition of combustion particles ("soot") depends strongly on its sources: some sources can produce almost pure elemental carbon, while others produce particles of which $50 \%$ by mass is organic matter (Medalia and Rivin, 1982). Graphite, the thermodynamically most stable form of pure elemental carbon, is an absolutely inert material under atmospheric conditions. It can be oxidized in air only at temperatures exceeding $600^{\circ} \mathrm{C}$. In graphitic structures, the carbon atom possesses an $\mathrm{sp}^{2}$ orbital hybridization, resulting in a hexagonally symmetric planar arrangement of carbon atoms connected by $\sigma$-bonds. The remaining p-electron is in an orbital perpendicular to the plane of carbon atoms. The p-orbitals overlap sideways to form $\pi$ bonds. Because of the infinite planar structure of the graphite sheets, the electrons in the overlapping p-orbitals are delocalized along the hexagonal atomic sheets of carbon. This accounts for graphite's metal-like properties, particularly its electrical conductivity and broad-band light absorption. This latter property is of utmost importance in the light absorption by soot particles, because it serves as a basis for the optical methods of their determination.

Graphitic structures in which carbon atoms occupy lattice sites in a two-dimensional honeycomb network (graphene 
layers) have intense Raman modes, but very weak IR vibrational absorption. These Raman modes enable unambiguous identification of graphitic structures in atmospheric aerosol, possibly as the only method available at a molecular level (Rosen and Novakov, 1977; Mertes et al., 2004). The shapes and intensities of Raman transitions are functions of the graphite crystal size, morphology and sample composition (Sze et al., 2001; Sadezky et al., 2005). High resolution transmission electron microscopy (HRTEM) revealed that the internal structure of combustion soot spherules depends strongly on the chemical and thermal environment under which they are formed and on the time available for annealing (Buseck et al., 1987; Su et al., 2004). Very rapidly formed soot particles are nearly amorphous, with only some signatures of short-range order (Pósfai et al., 1999; Grieco et al., 2000; Ferry et al., 2002; Wentzel et al., 2003), with fullerenic structures developing at slightly longer residence times in the combustion region. At longer annealing times (seconds to minutes) or higher temperatures, more highly ordered carbon structures develop.

Soot particles are usually thought to be insoluble in water and organic solvents. While this is definitely true for pure graphite, more atmospherically relevant types of combustion particles behave differently (Medalia and Rivin, 1982). For example, extraction of hexane soot particles with various solvents showed it to contain up to 33 mass- $\%$ soluble material, consisting of polyaromatic hydrocarbons (PAHs), oxygenated polyaromatic hydrocarbons, and a small fraction of aliphatic compounds (Akhter et al., 1985). Particles from biomass burning also contain a large water-soluble fraction, including light-absorbing substances (Hoffer et al., 2005; Decesari et al., 2006).

Although the average elemental composition of combustion particles is usually dominated by carbon (typically about $85-95 \% \mathrm{C}, 3-8 \% \mathrm{O}$, and $1-3 \% \mathrm{H}$ by weight in various types of soot particles (Ebert, 1990; Clague et al., 1999; Grieco et al., 2000; Ferry et al., 2002)), an atmospheric soot particle may be regarded as a complex three-dimensional organic polymer with the capability of transferring electrons, rather than merely an amorphous form of elemental carbon (Chang et al., 1982). The relatively low mass fraction of oxygen in soot carbon may be deceiving, since most of it is actually found on the surface in various functional groups, so that the soot particles do not behave as pure graphitic carbon in most atmospheric processes. The amount of oxygen at the surface of soot particles depends on combustion conditions, with more efficient combustion regimes resulting in higher abundance of oxygen and defective structures at the surface of the particles (Chughtai et al., 2002; Su et al., 2004). This in turn increases the chemical reactivity of the particles (including their thermochemical properties in soot analyzers) and their wettability in the atmosphere. The carbon-to-hydrogen mole ratio has been reported to be about 3-6 in diesel engine and exhaust soots and about 8-20 in carbon blacks (Cachier et al., 1989b; Ebert, 1990; Clague et al., 1999).
Despite the ample variations in morphology and chemistry, we propose to call this combustion-derived particle type "soot carbon" or $\mathrm{C}_{\text {soot}}$, as long as the identity of this species has been definitely established. However, the measurement techniques that are capable of doing so, such as Raman spectroscopy or electron microscopy, are absolutely impractical for routine monitoring of this important aerosol component.

To address this problem, various measurement methods have been developed and utilized for the quantification of this aerosol component on a routine basis, making use of some characteristic properties of $\mathrm{C}_{\text {soot }}$ (Rosen and Novakov, 1977; Ellis and Novakov, 1982; Cadle et al., 1983; Andreae et al., 1984; Gundel et al., 1984; Hansen et al., 1984; Heintzenberg, 1988; Cachier et al., 1989b; Hitzenberger et al., 1999; Schmid et al., 2001; ten Brink et al., 2004). Use of these methods has resulted in new operational definitions such as black carbon ("BC") or elemental carbon ("EC"), depending on the key property they are taking advantage of. "EC" is conventionally the preferred term in conjunction with thermal and wet chemical determinations, which are deemed suitable for the selective measurement of the refractory component. The term "BC" implies that this component is responsible for the absorption of visible light, and is generally used when optical methods are applied for its determination. It is important to note that neither category corresponds in a unique way to a specific atmospheric particle type, and that ambient soot or LAC particles represent a range of material properties that respond in different ways to the various analytical techniques. Both "BC" and "EC" can only be regarded as "proxies" for the concentration of soot carbon, whose accuracies depend on the similarity between atmospheric soot particles and the species used for calibration. If atmospheric soot particles were pure graphite and all the methods were calibrated against graphite, "BC" and "EC" readings would give exactly the mass concentration of soot carbon as intended. But since graphite is only a trace component of atmospheric particles, "BC" and "EC" measurements usually give different results, which may have little in common with the "true" mass concentrations of atmospheric soot particles. In the literature, however, these discrepancies are usually disregarded and the terms "BC" and "EC" are used interchangeably as synonyms for $\mathrm{C}_{\text {soot }}$.

To highlight that "EC" is not strictly "elemental" carbon in a chemical sense, but rather an operationally defined component, we shall use the term $\mathrm{EC}_{\mathrm{a}}$ ("apparent elemental carbon") in this paper. Similarly, since "BC" is operationally defined as that amount of pure $\mathrm{C}_{\text {soot }}$ (with an absorption cross section of ca. $7.5 \mathrm{~m}^{2} \mathrm{~g}^{-1}$; Bond and Bergstrom, 2006) that would produce the same absorption signal as the sample (Bond et al., 2004), we shall use the term $\mathrm{BC}_{\mathrm{e}}$ ("equivalent black carbon") here. When we refer in general to all forms of light absorbing carbonaceous aerosols, we shall use the term "light absorbing carbon" (Malm et al., 1994).

It is conventionally assumed in atmospheric science, especially in climate-related discussions, that "BC" (there used 


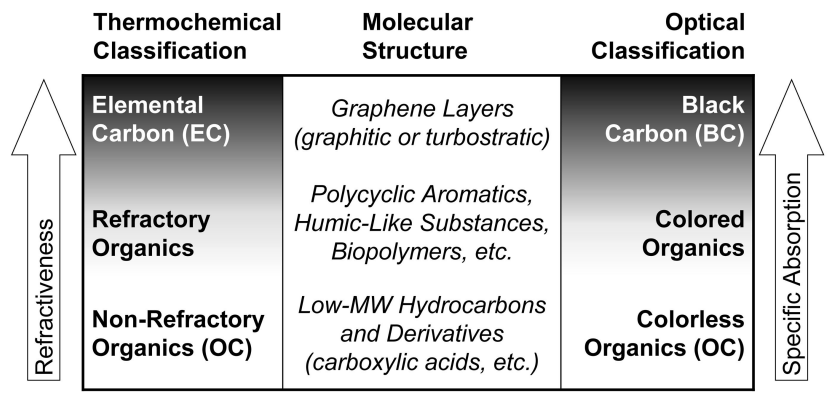

Fig. 1. Classification and molecular structure of carbonaceous aerosol components (from Pöschl, 2003).

synonymously with soot carbon) is the only light-absorbing component of submicron aerosol. In addition, "BC" is very often considered as a single specific entity throughout the atmosphere, originating from combustion as the sole source, and having a black color and uniform chemical composition and physical properties. This view has remained popular in spite of the fact that a single material constant for the refractive index of atmospheric light-absorbing carbon (LAC) does not exist: its value is dependent on the type of the fuel and the conditions of combustion (Bond and Bergstrom, 2006). The refractive index of LAC, together with size and density, are key parameters in the Lorentz-Mie calculation of the mass absorption efficiency $\left(\alpha_{\mathrm{abs}}\right)$ of a single soot particle. Bond and Bergstrom (2006) have recently re-analyzed the literature data on the refractive index and mass absorption efficiency of uncoated ("naked") soot particles, considering only traceable actual measurements, rather than a mixture of measurements, secondary references and models. They suggest that some of the previously reported uncertainty is related to inaccurate analysis of literature data in previous reviews, and propose a value of $\alpha_{\mathrm{abs}}=7.5 \pm 1.2 \mathrm{~m}^{2} \mathrm{~g}^{-1}$ for pure soot carbon particles. Higher absorption cross-sections result from coating processes in the atmosphere (see also Sect. 2.2.2).

Recently, it has become clear that certain organic compounds in addition to $\mathrm{C}_{\text {soot }}$ may also contribute to light absorption in atmospheric aerosols. There has been mounting evidence from chemical aerosol measurements, laboratory studies, or direct measurements of the spectral dependence of light absorption (Mukai and Ambe, 1986; Havers et al., 1998b; Hoffer et al., 2005) that there is a continuum of carbonaceous substances in atmospheric aerosols (Fig. 1, from Pöschl, 2003). At one end is the thermally refractory and strongly light absorbing near-elemental "EC" or $\mathrm{C}_{\text {soot }}$ and at the other extreme are thermally reactive and colorless organic substances, such as most hydrocarbons. Although the mass absorption efficiency of light-absorbing organic species at the wavelength of $550 \mathrm{~nm}$ is much less than that of $\mathrm{C}_{\text {soot }}$, it increases sharply towards lower wavelengths, making their absorption in the UV potentially significant due to their observed high abundance in continental aerosol (Kirchstetter et al., 2004; Hoffer et al., 2005). This spectral dependence causes the material, or its solution, to appear brown (or yellow). In analogy to soot carbon, we propose to call these species collectively $\mathrm{C}_{\text {brown }}$, highlighting their optical properties as well as their uncertain origin and chemical composition.

It was observed that particles from smoldering combustion (Patterson and McMahon, 1984), or from residential coal combustion (Bond, 2001) can contain substantial amounts of $\mathrm{C}_{\text {brown }}$. This particulate matter appears light brown to yellowish, and not black as would be expected for pure soot particles (Bond et al., 1998; Bond, 2001). This was especially true for the initial period of the combustion, when yellow particles were released in great abundance. It was speculated that weakly absorbing coal tar, consisting of partially aromatized organic matter, can escape from the coal matrix by devolatilization, then undergo thermal processing leading to a progressively greater degree of graphitization. Thus, aromatic compounds emitted from bituminous coal combustion may cover a continuum from a few conjugated aromatic rings (coal tar) to an extended network of aromatic rings $\left(\mathrm{C}_{\mathrm{soot}}\right)$. The higher degree of graphitization means that the energy gap between the highest ground state and the lowest excited state is smaller, which enhances absorption efficiency and simultaneously shifts absorption towards longer wavelengths (lower energy).

Similar processes may take place during the pyrolysis of organic matter, especially during biomass combustion (Mukai and Ambe, 1986). Pyrolysis products can escape without being combusted in flames, and then condense in the cooling plume. Thus they become associated with submicron particles, characteristic of secondary aerosols. Since lignin pyrolysis products are substituted aromatic compounds, they may behave similarly to bituminous coal combustion products. Lignin pyrolysis products were identified in biomass burning aerosol. In addition, there may be some of the solid products of the charring process emitted as aerosol. Most of this char material is expected to end up as supermicron particles, typical of primary aerosols. Because these particles are porous and light, however, their aerodynamic diameter may be much smaller than their geometric diameter, and they may end up in the "submicron" fraction of impactor or stacked filter samples.

Light-absorbing carbonaceous aerosols can also originate from processes other than combustion, particularly from biogenic materials and their low-temperature oxidation and polymerization products (Andreae and Crutzen, 1997). The bulk characterization of organic carbon in fine continental aerosol, in particular of its water-soluble fraction, revealed that it contains substantial amounts of material with properties closely resembling those of natural humic/fulvic substances, such as their IR, UV, and visible spectra, NMR spectra, mass spectra, chemical composition, affinity to chromatographic resins, and solubility (Havers et al., 1998a; Zappoli et al., 1999; Gelencsér et al., 2000a; Gelencsér et al., 
2000b; Krivácsy et al., 2000; Decesari et al., 2001; Kiss et al., 2001; Krivácsy et al., 2001). Natural humic/fulvic substances are known to result from the conversion of plant degradation products into polymeric substances with a high degree of aromaticity. Such components make up much of what are usually referred to as humic and fulvic acids, and provide the light absorbing component of dark soils, swamp waters, and black tea. Filters loaded with macroscopic amounts of fulvic or humic acid samples look very dark brown or nearly black (Fig. 2). Tannin/lignin compounds which have similar properties were identified in precipitation (Likens et al., 1983), whereas in cloud water insoluble black particles with the distinguishing infrared absorption bands for both protein and cellulose, and brown particles with the imprint of decomposed proteins have been observed (Bank and Castillo, 1987).

Besides originating directly from biomass burning or decomposition, colored polymeric products ("HUmic-LIke Substances", HULIS) might also form in heterogeneous reactions from dienes like isoprene in the presence of sulfuric acid (Limbeck et al., 2003). Aromatic hydroxy acids, which are emitted in vast quantities by the pyrolysis of lignin during biomass burning, yield colored products in multiphase reactions with $\mathrm{OH}$ radicals under typical conditions prevalent in cloud water (Gelencsér et al., 2003). Another path for the formation of $\mathrm{C}_{\text {brown }}$ may be reactions of organic compounds in sulfuric acid particles at low humidities (Hegglin et al., 2002).

All these findings point to the important fact that in the atmosphere a single uniform entity of "BC" does not exist: on one hand, $\mathrm{C}_{\text {soot }}$ already has a wide range of chemical and physical properties, which renders any attempt for generalization highly uncertain; on the other hand, there is clearly a substantial fraction of organic matter in fine atmospheric aerosol, which is light-absorbing, but has properties and origins very much different from soot carbon and which is definitely not black. The term "brown carbon" $\left(\mathrm{C}_{\text {brown }}\right)$ that we propose here is meant to represent the latter, though it could include the "tail" of the properties of combustion soot carbon. These moderately-to-weakly absorbing particles could in part originate from low-temperature combustion processes (e.g., biomass burning or lignite combustion), or could even be produced in the atmosphere in heterogeneous or multiphase processes. Generally speaking, the LAC in aerosol equals the sum of $\mathrm{C}_{\text {soot }}$ and $\mathrm{C}_{\text {brown }}$.

In the following we will review how the existence of $\mathrm{C}_{\text {brown }}$ may change our understanding of atmospheric LAC and atmospheric light absorption in general. For this purpose we need to know the physical and chemical properties of $\mathrm{C}_{\text {brown }}$, particularly in relation to those of soot carbon. Although $\mathrm{C}_{\text {brown }}$ does denote an existing component of atmospheric aerosol, it possibly covers a wide range of chemical and physical properties that are very difficult to measure, and even more difficult to generalize. In other words, contrary to $\mathrm{C}_{\text {soot }}$, for which surrogates such as $\mathrm{BC}_{\mathrm{e}}$ or $\mathrm{EC}_{\mathrm{a}}$ exist that are

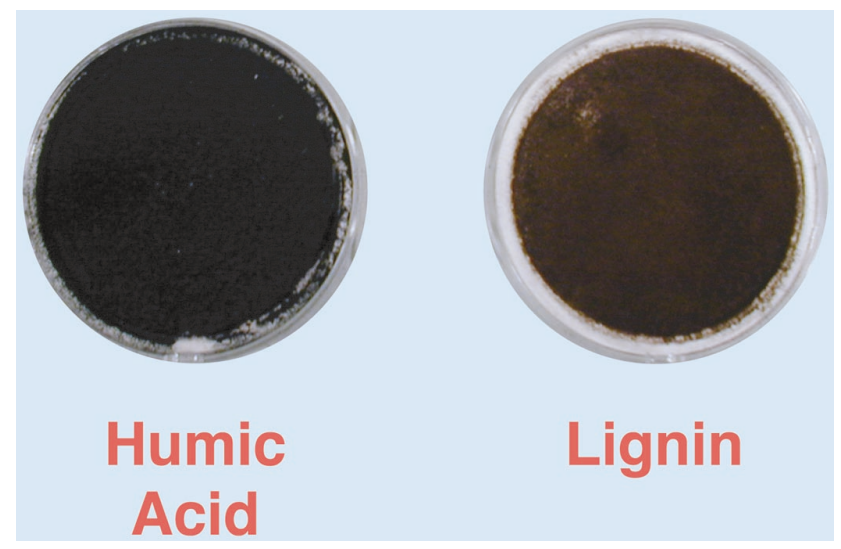

Fig. 2. Filters loaded with commercial samples of humic acid (Fluka 53680) and lignin (Aldrich 37,095-9). Filter loading is comparable to heavily loaded urban aerosol samples.

widely used for its representation in atmospheric science, no such surrogate can be meaningfully defined for $\mathrm{C}_{\text {brown }}$. One might argue that natural humic or fulvic acids may be suitable for representing the fundamental properties of $\mathrm{C}_{\text {brown }}$, as has been proven in a series of studies on atmospheric aerosol (Havers et al., 1998a; Zappoli et al., 1999; Krivácsy et al., 2000; Kiss et al., 2001; Krivácsy et al., 2001; Graber and Rudich, 2006), and was suggested by Fuzzi et al. (2001). However, terrestrial or aquatic humic and fulvic acids are not single chemical species, but operationally defined classes of compounds, which themselves exhibit an extremely wide range of physico-chemical properties. Therefore, any arbitrarily selected "reference" material as a surrogate is unlikely to be suitable for the representation of the wide variety of $\mathrm{C}_{\text {brown }}$ in the atmosphere. Nevertheless, in discussing the role of $\mathrm{C}_{\text {brown }}$ in atmospheric light absorption, we will rely on the properties of HULIS observed in the water-soluble fraction of aerosol and sometimes on those of "standard" humic and fulvic acids (Graber and Rudich, 2006).

\section{Interference of $\mathrm{C}_{\text {brown }}$ with $\mathrm{EC}_{\mathrm{a}}$ and $\mathrm{BC}_{\mathrm{e}}$ measure- ments}

\subsection{Thermochemical analysis ("EC")}

The accurate sampling and determination of carbonaceous species in atmospheric aerosols has been recognized as one of the most difficult challenges facing atmospheric chemists (Huebert and Charlson, 2000). The most common methods for the determination of $\mathrm{OC}, \mathrm{BC}_{\mathrm{e}}$ or $\mathrm{EC}_{\mathrm{a}}$ are simple thermal, optical, or more recently, thermal-optical methods. The presence of significant concentrations of $\mathrm{C}_{\text {brown }}$ in tropospheric fine aerosol may cause substantial bias in any of the traditional measurement techniques, resulting in erroneous $\mathrm{BC}_{\mathrm{e}}$ or $\mathrm{EC}_{\mathrm{a}}$ concentration values, which are subsequently carried 


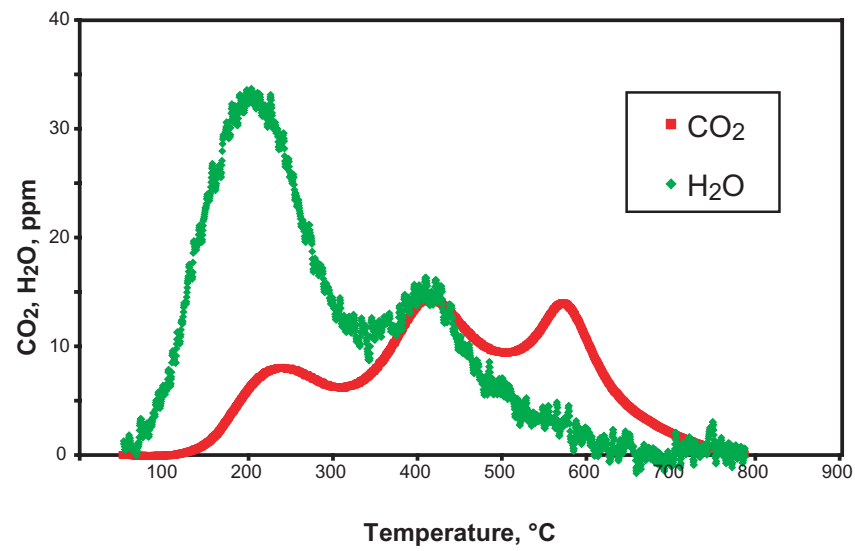

Fig. 3. Carbon and hydrogen thermogram of a water-extracted sample of pyrogenic aerosol from the Amazon region.

on to calculations of atmospheric light absorption and into climate models.

Thermochemical analysis was originally applied to urban aerosols, including particularly diesel soot (Ellis and Novakov, 1982; Cadle et al., 1983; Cachier et al., 1989a; Birch and Cary, 1996). This type of analysis, also referred to as "Evolved Gas Analysis" (EGA), consists of controlled heating of the sample in a stream of gas, so that organic compounds and soot carbon are successively volatilized and oxidized to $\mathrm{CO}_{2}$, which is then transferred to a detector and either measured directly or after conversion to $\mathrm{CH}_{4}$. The total carbon (TC) content of the sample is determined from the integral of the $\mathrm{CO}_{2}$ emitted over the entire temperature range, while the organic carbon (OC) fraction is defined as the amount of $\mathrm{CO}_{2}$ released up to a certain threshold temperature. The carbon fraction combusted above this threshold temperature, our $\mathrm{EC}_{\mathrm{a}}$, has usually been called "elemental carbon", because it is assumed that it represents the $\mathrm{C}_{\text {soot }}$ fraction of the aerosol, which is thought to have a nearly elemental composition. This is most applicable to diesel soot or lamp black, where black carbon is nearly identical with soot carbon and has a chemical composition close to elemental carbon. In thermograms of samples where $\mathrm{C}_{\text {soot }}$ dominates, there is usually a clearly defined peak at high temperatures $\left(>450^{\circ} \mathrm{C}\right)$. HR-TEM investigation of diesel soot particles has shown them to have near-spherical structure with onion-like graphene layers. Because the reactivity of carbon phases increases with the amount of free-edge carbon and structural hetero-atoms, diesel soot with its spherical structure and high carbon content is the most refractory environmental carbon phase, and is therefore most readily separated from organic carbonaceous aerosol components (Gustafsson et al., 2001).

Severe difficulties are encountered, however, when this type of analysis is applied to samples containing brown carbon from biomass burning (Reid et al., 2005) or humic materials. First, because of the ill-defined chemical nature of
$\mathrm{C}_{\text {brown }}$, it is volatilized over a wide range of temperatures in thermochemical analysis. Some of it therefore is classified as organic carbon, some as "elemental" carbon (MayolBracero et al., 2002). Second, the chemical composition of the aerosol sample and filter substrate can influence the temperature at which $\mathrm{EC}_{\mathrm{a}}$ is evolved (Lin and Friedlander, 1988). In particular, biomass smoke contains inorganic components that catalyze oxidation of $\mathrm{C}_{\mathrm{soot}}$ and $\mathrm{C}_{\text {brown }}$, shifting their combustion to lower temperatures (Novakov and Corrigan, 1995). Generally, it has been found that "EC" in aged and remote aerosols evolves at considerably lower temperatures $\left(450-550^{\circ} \mathrm{C}\right.$ instead of $\left.550-700^{\circ} \mathrm{C}\right)$ than in urban aerosols (Turner and Hering, 1994; Huffman, 1996b). In thermochemical procedures with a fixed temperature sequence, where the distinction between $\mathrm{EC}_{\mathrm{a}}$ and $\mathrm{OC}$ is made solely based on combustion temperature (e.g., the R\&P 5400 Ambient Carbon Particulate Monitor), a misidentification of $\mathrm{C}_{\mathrm{soot}}$ as organic carbon, and a reduction in the fraction of $\mathrm{C}_{\text {brown }}$ that is classified as $\mathrm{EC}_{\mathrm{a}}$ may result. Conversely, when the last peak in a thermogram is simply interpreted as representing $\mathrm{EC}_{\mathrm{a}}$, without considering the convergence of $\mathrm{EC}_{\mathrm{a}}$ and $\mathrm{OC}$ combustion temperatures by catalytic effects, $\mathrm{EC}_{\mathrm{a}}$ concentrations may be drastically overestimated (by a factor of 2-10) (Novakov and Corrigan, 1995; Mayol-Bracero et al., 2002).

In view of the difficulty of ascertaining the identity of $\mathrm{EC}_{\mathrm{a}}$ based solely on its thermal behavior, it may be useful to also use potentially available chemical information. The $\mathrm{H} / \mathrm{C}$ molar ratio in $\mathrm{C}_{\text {soot }}$ is ca. $0.15 \pm 0.05$, well below that of organic substances, where it usually exceeds 1.0 , except in highly condensed materials (PAH, humics, lignin) where it tends to cluster in the range 0.5-1.5 (Cachier et al., 1989b; Huffman, 1996b; Kim et al., 2003; Kramer et al., 2004). Atmospheric HULIS have H/C ratios of about 1.4-1.6 (Graber and Rudich, 2006). This could provide a diagnostic feature in thermograms made with instruments having a $\mathrm{H}_{2} \mathrm{O}$ channel in addition to the usual $\mathrm{CO}_{2}$ detector channel (Kuhlbusch et al., 1998). This possibility has remained little explored, even though detectors that provide simultaneous determination of $\mathrm{H}_{2} \mathrm{O}$ and $\mathrm{CO}_{2}$ are widely available, e.g., the LI-6262 or LI7000 (LI-COR Biosciences, Lincoln, NE 68504, USA). Figure 3 shows a thermogram from a sample of biomass smoke collected in the Amazon during the LBA-SMOCC campaign (Andreae et al., 2004), which had been water-extracted before analysis. There is a clear differentiation between the three peaks based on the $\mathrm{H} / \mathrm{C}$ ratio: The first peak, which represents the most volatile compounds, has an $\mathrm{H} / \mathrm{C}$ ratio of $\sim 4$, and probably still contains some absorbed water from the extraction procedure (note that the thermogram shows $\mathrm{H}_{2} \mathrm{O}$, with two $\mathrm{H}$ atoms per molecule). The second peak has an $\mathrm{H} / \mathrm{C}$ ratio near 2 , similar to cellulose and lignin compounds, while the third peak, above $500^{\circ} \mathrm{C}$, shows a much lower $\mathrm{H} / \mathrm{C}$ of about 0.4 , near but somewhat above that reported for $\mathrm{C}_{\text {soot }}$.

In addition to these conceptual and technical difficulties with the distinction between $\mathrm{C}_{\text {soot }}$ and $\mathrm{C}_{\text {brown }}$, charring of 
organic compounds, i.e. the formation of black char during thermochemical analysis, is one of the major artefacts in these procedures. Some methods carefully optimize experimental conditions in order to minimize the extent of charring, such as the two-step combustion procedure developed by Cachier et al. (1989a). Although charring can largely be avoided in this method for various organic matrices, the authors themselves found that humic acids undergo charring up to $37 \pm 3 \%$ by mass. Given the diversity of compounds that contribute to $\mathrm{C}_{\text {brown }}$, it is not known whether $\mathrm{C}_{\text {brown }}$ is also prone to charring, and what the consequences of that would be for the apparent "OC" and "EC" concentrations obtained from such an analysis. One could argue that the brown carbon from biomass burning is not very susceptible to charring, given that it has been volatilized in a fire. This is, however, contradicted by the findings that water-soluble organic carbon (WSOC), which is a major component of pyrogenic aerosols and contains a significant amount of $\mathrm{C}_{\text {brown }}$, has been shown to be especially prone to charring (Yu et al., 2002; Yu et al., 2004). This also applies to the most abundant organic compound in pyrogenic aerosols, levoglucosan. These issues have been largely ignored, because at the time the EGA method was developed, nothing was known about the presence of HULIS in fine aerosol, but recently it has become obvious that "EC" values measured in the presence of considerable amounts of $\mathrm{C}_{\text {brown }}$ (as is likely the case for biomass burning aerosol and continental fine aerosol in general) may be overestimated by some variants of thermochemical analysis.

Extraction of the sample with water or organic solvents prior to thermochemical analysis has been proposed as a technique to reduce charring and interference by $\mathrm{C}_{\text {brown }}$ (Novakov and Corrigan, 1995; Mayol-Bracero et al., 2002; Kirchstetter et al., 2003). Water extraction removes both inorganic catalytic compounds and at least part of the $\mathrm{C}_{\text {brown }}$, providing a closer approximation of the actual $\mathrm{C}_{\text {soot }}$ content by $\mathrm{EC}_{\mathrm{a}}$. The removal of the WSOC considerably reduces the charring artefact. Organic solvents also remove organic carbon and part of $\mathrm{C}_{\text {brown }}$, but do not eliminate the catalytic effect of inorganic ions.

Another strategy to cope with the problem of charring is implemented in thermal-optical analysis, which has been proposed as the most accurate method for the $\mathrm{OC} / \mathrm{EC}_{\mathrm{a}}$ split. In this method, the transmittance or reflectance of the filter sample is monitored during the thermographic analysis (Chow et al., 1993; Birch and Cary, 1996). The transmittance initially decreases with heating due to charring of organic matter, and then increases again, as the char is combusted. The cut-point between $\mathrm{OC}$ and $\mathrm{EC}_{\mathrm{a}}$ is defined as that point in the thermogram at which transmittance has returned to the value it had before charring. This optical pyrolysis correction assumes that the light extinction per unit mass of pyrolytically produced carbon is the same as the light extinction per unit mass of carbon removed until the reflectance regains its initial value. Since this condition is unlikely to always be met, there is an inherent bias in either direction in the demarcation between $\mathrm{OC}, \mathrm{C}_{\text {brown }}$ and $\mathrm{C}_{\text {soot }}$. In an analysis of the data set from the IMPROVE aerosol network in the United States, Huffmann (1996a; 1996b) has shown that the charring correction in the thermal-optical reflectance technique and the misinterpretation in the $\mathrm{OC}-\mathrm{EC}_{\mathrm{a}}$ cutpoint can lead to a large underestimation of $\mathrm{EC}_{\mathrm{a}}$. In a recent comparison between $\mathrm{EC}_{\mathrm{a}} / \mathrm{OC}$ determinations by the thermal-optical reflectance (TOR) and thermal-optical transmission (TOT) techniques, differences by as much as a factor of 4 were observed for the $\mathrm{EC}_{\mathrm{a}}$ concentrations obtained with the two variants of the technique (Chow et al., 2004). These differences could be attributed to charring within the filter matrix, which introduced a bias in the TOT technique (Chen et al., 2004).

In intercomparisons of a large number of techniques for the determination of TC, OC and $\mathrm{EC}_{\mathrm{a}}$, the agreement is usually quite good for $\mathrm{TC}$, but very poor for the determination of the $\mathrm{EC}_{\mathrm{a}}$ fraction (Countess, 1990; Hitzenberger et al., 1999; Schmid et al., 2001; ten Brink et al., 2004; Watson et al., 2005). Typically, the $\mathrm{EC}_{\mathrm{a}}$ measurements are highly correlated between methods, but the slopes differ strongly from unity, indicating that the differences are of a systematic nature. While the various thermal-optical and EGA techniques usually agree reasonably well (better than a factor of two discrepancy) for laboratory soot, gasoline and diesel engine emissions, and urban particulates (Countess, 1990; Guillemin et al., 1997; Lim et al., 2003), huge differences (up to factors of six, and occasionally even more) are seen for samples from non-urban areas and biomass burning emissions (Chow et al., 2001; Schmid et al., 2001). But even for the new standard reference materials, RM 8785 (Air Particulate Matter on Filter Media), two different thermal-optical protocols (IMPROVE and STN-NIOSH) yielded unreconciled differences of a factor of 2 (Klouda et al., 2005), so that the material has been issued with two different so-called "information concentration values" (based on the two different protocols) for $\mathrm{EC}_{\mathrm{a}}$ !

The good agreement between various methods for analyzing diesel exhaust particulates is understandable since, as discussed above, they exhibit a clearly ordered layer structure approaching that of polycrystalline graphite, and contain very little polymeric organic material. This is supported by the studies of Wittmaack $(2004,2005)$, who found that urban soot particles, presumably from diesel emissions, were thermally stable in air up to $470^{\circ} \mathrm{C}$, and then oxidized in a narrow temperature interval between 480 and $510^{\circ} \mathrm{C}$. However, large uncertainty is associated with the thermal-optical measurements of aerosol containing a large fraction of $\mathrm{C}_{\text {brown }}$ and pyrolysable OC. In a recent study, a thermal-optical method was tested on atmospheric aerosol, wood smoke, coal fly ash, and secondary organic aerosol from smog-chamber experiments, and on organic matrices such as wood smoke extract, candle wax and motor oil (Schauer et al., 2003). It was found that all ambient atmospheric aerosol samples pyrolyzed during analysis, as did wood smoke, secondary organic aerosol 

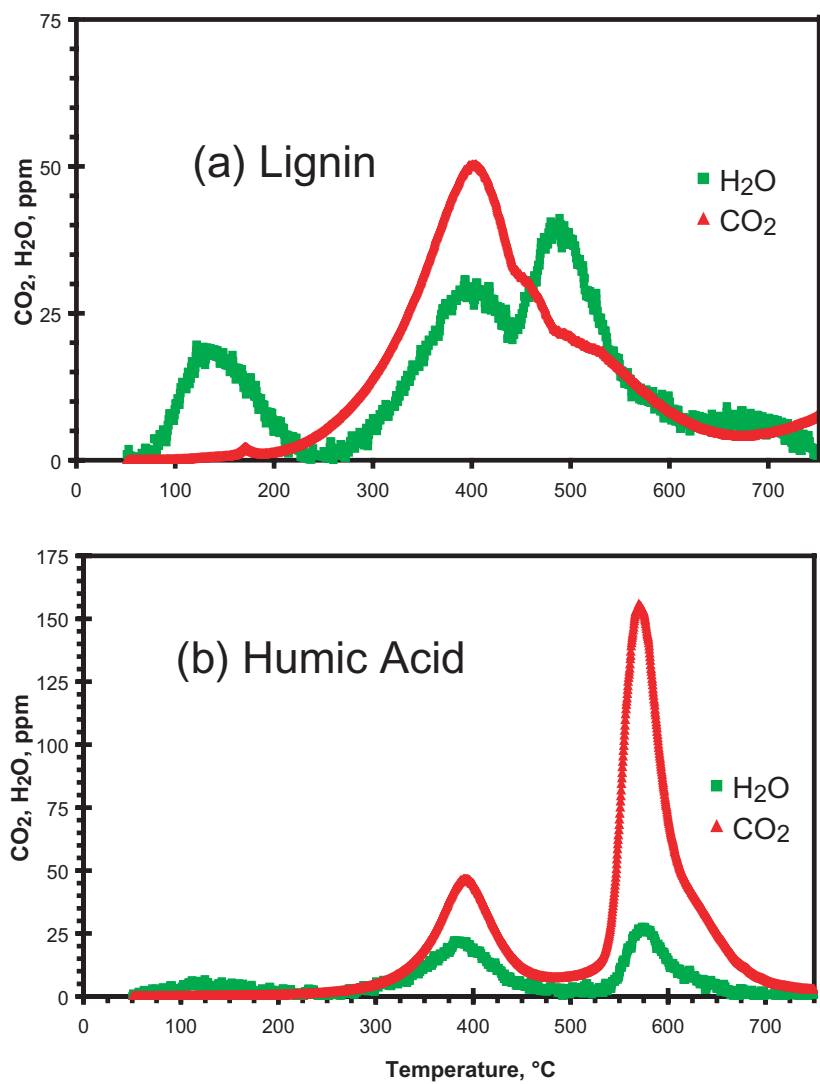

Fig. 4. Carbon and hydrogen thermograms of commercial samples of (a) lignin (Aldrich 37,095-9) and (b) humic acid (Fluka 53680).

(SOA), and wood smoke extract. Even with an optimized 10step temperature program it was not possible to fully correct for charring. The key outcome was that elemental carbon was detected by the thermal-optical method in samples in which it should not be present, e.g., wood smoke extract and SOA, and that the measurement of $\mathrm{EC}_{\mathrm{a}}$ was biased by some organic matrices. For example, in the wood smoke extract, $5 \%$ of the carbon was falsely assigned as elemental by the thermaloptical method. Another study revealed that for SOA generated in a smog-chamber, which contained no $\mathrm{C}_{\text {soot }}, \sim 2 \%$ of total carbon was erroneously interpreted to be "EC" (in the sense of soot particles) by a thermal-optical method (Chow et al., 1993). Note that a relatively small percentual bias in the determination of $\mathrm{OC}$ can result in a very large bias in the $\mathrm{EC}_{\mathrm{a}}$ measurement, since $\mathrm{OC}$ is typically about 10 times more abundant than $\mathrm{EC}_{\mathrm{a}}$. EGA thermograms of non-urban aerosols suggest that a significant fraction of OC is combusted in the temperature range normally associated with $\mathrm{C}_{\text {soot}}$, and therefore would be incorrectly assigned to the "EC" fraction. Some types of bioaerosol particles, which are likely to be light-absorbing as well, require combustion temperatures well above $600^{\circ} \mathrm{C}$ (Wittmaack, 2005). In summary, we find that combustion temperatures can be uniquely associated with specific types of carbonaceous aerosol $\left(\mathrm{C}_{\text {soot }}\right.$,
"EC", OC) only for a few very clearly defined aerosol types, e.g., pure diesel soot. In the more general case of mixed aerosols, the combustion temperatures of $\mathrm{C}_{\mathrm{soot}}$ and the various forms of OC (including $\mathrm{C}_{\text {brown }}$ ) overlap to a significant extent.

A further example for these problems is provided by the EGA thermograms of commercial samples of humic acid and lignin, both of which are dark brown to black substances $\left(\mathrm{C}_{\text {brown }}\right)$, visually resembling "EC" (Fig. 4). The lignin sample is combusted almost completely below $600^{\circ} \mathrm{C}$, and the ratio of the $\mathrm{H}_{2} \mathrm{O}$ and $\mathrm{CO}_{2}$ signals suggests that the $\mathrm{H} / \mathrm{C}$ molar ratio ranges from about $1-4$, with an average of 1.3 , which is within the range previously reported for lignins (Kim et al., 2003). The humic acid sample, on the other hand, has a mean $\mathrm{H} / \mathrm{C}$ of 0.46 for the low temperature peak and a pronounced peak near $600^{\circ} \mathrm{C}$, which would in an unknown sample be usually interpreted as evidence of a large $\mathrm{C}_{\text {soot }}$ fraction. Even the $\mathrm{H} / \mathrm{C}$ ratio of ca. 0.3 in the latter peak, resulting from the combustion of thermally refractory organic material, is difficult to distinguish from that of $\mathrm{C}_{\text {soot }}$. The presence of comparably hydrogen-deficient fractions in riverine dissolved organic matter has been interpreted as evidence for the presence of "BC" from charred biomass (Kim et al., 2004), but it is plausible that similar materials can also be produced by (bio)chemical condensation polymerization.

The response of the thermal or thermal-optical techniques to the light-absorbing substances in biomass smoke has not been adequately characterized, but seems to be very dependent on the instrumental settings (Conny et al., 2003). Birch and Cary (1996) note that with an "optimized" setting they find only $0.86 \% \mathrm{EC}_{\mathrm{a}}$ in cigarette smoke, while with a "less than optimal" setting 20-30\% of the carbon in cigarette smoke was designated elemental. Furthermore, thermal analysis of starch and cellulose in the presence of $\mathrm{NH}_{4} \mathrm{HSO}_{4}$ produced 2-3 times the amount of char than was formed in the absence of the inorganic compound, while the charring of levoglucosan decreased in the presence of $\mathrm{NH}_{4} \mathrm{HSO}_{4}$ (Yu et al., 2002).

An additional complication for thermal-optical measurements is presented by the fact that the spectral absorption of $\mathrm{C}_{\text {brown }}$ differs from that of black carbon. The absorption cross section of $\mathrm{C}_{\text {brown }}$ increases very sharply with decreasing wavelength, with a slope of $\lambda^{-2}$ to $\lambda^{-6}$, whereas $\mathrm{C}_{\mathrm{soot}}$ (e.g., from diesel vehicles) shows a $\lambda^{-1}$ dependence (Kirchstetter et al., 2004; Hoffer et al., 2005; Schmid et al., 2005) (see also Sect. 3). At the red wavelength of the HeNe laser $(632.8 \mathrm{~nm})$ used in the thermal-optical instrument, $\mathrm{C}_{\text {brown }}$ absorbs much less than $\mathrm{C}_{\mathrm{soot}}$, so that the $\mathrm{C}_{\text {brown }}$ fraction remains nearly invisible to the instrument. As a result, the instrument will interpret the fraction of $\mathrm{C}_{\text {brown }}$ combusted before the EC cutpoint as OC, the more refractory part as EC. Thus, part of $C_{\text {brown }}$ will be counted as OC, the rest as $E_{a}$. Since the optical properties of $\mathrm{C}_{\text {brown }}$ are different from those of $\mathrm{C}_{\text {soot }}, \mathrm{EC}_{\mathrm{a}}$ can then not be used as a valid proxy for LAC any more. 


\subsection{Light absorption measurements (“BC")}

In principle, the relatively strong light absorption of $\mathrm{C}_{\text {soot }}$ can be utilized to infer $\mathrm{C}_{\text {soot }}$ from an optical measurement of aerosol light absorption $\left(\sigma_{\text {abs }}\right)$ and knowledge of the massspecific absorption of $\mathrm{C}_{\text {soot }}\left(\alpha_{\mathrm{abs}}\right)$. This approach has the advantage, from a climate perspective, that the primary measurement relates directly the light-absorbing properties of the aerosol, without consideration of whether the absorption is due to $\mathrm{C}_{\text {soot }}$ or $\mathrm{C}_{\text {brown }}$. In this section, we will discuss the various problems associated with this approach: (1) many of the presently used instruments introduce a substantial bias into the determination of aerosol light absorption, (2) there are no reference standards for measurements of light absorption by ambient aerosols, (3) there is no unique conversion factor $\left(\alpha_{\mathrm{abs}}\right)$ between light absorption and $\mathrm{C}_{\text {soot }}$ concentration in ambient aerosols, and (4) the difference in spectral properties between $\mathrm{C}_{\text {soot }}$ and $\mathrm{C}_{\text {brown }}$, as well as the chemical complexity of $\mathrm{C}_{\text {brown }}$, lead to several conceptual as well as practical complications.

\subsubsection{Problems related to the measurement of aerosol light absorption}

Significant uncertainties are associated with the determination of aerosol light absorption, $\sigma_{\text {abs }}$. For atmospheric applications, the only instrument that can measure light absorption directly on an airborne aerosol is the photoacoustic spectrometer (PAS) (Truex and Anderson, 1979; Yasa et al., 1979; Petzold and Niessner, 1995; Moosmüller et al., 1997; Arnott et al., 1999). In principle, light absorption by airborne aerosols can also be determined by the so-called "difference method", where absorption is determined from the difference between extinction and scattering as measured by an extinction cell and a nephelometer, respectively (Schnaiter et al., 2005b; Sheridan et al., 2005). Comparison experiments with the PAS and optical extinction cells show excellent agreement for a wide variety of aerosols including diesel soot, biomass smoke particles and ambient aerosol (Petzold et al., 2005; Schnaiter et al., 2005b). While this method is useful for the validation of absorption techniques with high concentrations of relatively "dark" aerosols (single scattering albedo at $550 \mathrm{~nm}$ less than $\sim 0.8$ ), it results in unacceptably large errors for typical atmospheric conditions, since it determines $\sigma_{\text {abs }}$ from a fairly small difference of two large numbers (extinction and scattering coefficient) (Schnaiter et al., 2005b; Sheridan et al., 2005).

Historically, absorption measurements have most frequently been performed with on-line "integrating plate" techniques (e.g., aethalometer and particle soot absorption photometer, PSAP), which deposit aerosol onto a filter and measure the resulting change in light transmittance through the filter. It must be noted that these techniques do not directly determine $\sigma_{\mathrm{abs}}$, i.e., the absorption by the ambient aerosol, but $\sigma_{\mathrm{ATN}}$, the attenuation coefficient through an aerosol- laden filter (see also Sect. 2.2.2). As a result of the fact that these measurements are not done on airborne aerosols, but on samples deposited on a filter, there are a variety of artefacts mainly due to filter-aerosol interactions (multiple scattering), shadowing of the incident light with increasing filter loading, and aerosol scattering effects (Petzold et al., 1997; Weingartner et al., 2003; Arnott et al., 2005). In a study where several filter-based measurements of the absorption coefficient of biomass smoke were compared, the systematic disagreement between methods was "only" $20-40 \%$, but individual measurements often differed by a factor of three (Reid et al., 1998b).

Although numerous efforts have been made to calibrate aethalometers and PSAPs and to correct for the various artefacts (Hansen et al., 1984; Bodhaine, 1995; Bond et al., 1999a), no generally valid calibration or correction scheme for ambient aerosol has become available due to the complex interaction of physical aerosol properties (size, single scattering albedo, mixing state) and the filter matrix. Comparisons of simultaneous measurements made using PAS and filter-based techniques (PSAP, aethalometer, integrating plate) show considerable differences (up to a factor of two) under some circumstances, especially when the relative humidity is variable (Moosmüller et al., 1998; Arnott et al., 1999; Arnott et al., 2003; Sheridan et al., 2005). The most reliable filter-based instrument for absorption measurements at this time is the multi-angle absorption photometer (MAAP), which simultaneously measures transmittance and reflectance of the filter at multiple angles and uses a twostream radiative transfer model to determine the filter and aerosol scattering corrections for the absorption measurement (Petzold and Schönlinner, 2004).

Overall we conclude that, depending on which technique is used and what corrections are applied, systematic errors of up to a factor of two must be expected when inferring the true in-situ absorption coefficient from filter-based absorption measurements, unless these are carefully corrected for filter and scattering effects. On the other hand, laboratory comparisons between the PAS and difference method suggest that the PAS can determine aerosol absorption with an accuracy <10\% (Moosmüller et al., 1998; Arnott et al., 1999; Arnott et al., 2003; Sheridan et al., 2005).

\subsubsection{Problems related to the relationship of $\mathrm{C}_{\text {soot }}$ mass concentration and light absorption}

When absorption is measured with the intention to derive "black carbon" concentrations, a measured or assumed specific absorption cross section $\left(\alpha_{\text {abs }}\right)$ must be used to convert light absorption to mass concentration of $\mathrm{BC}_{e}$. As mentioned above, Bond and Bergstrom (2006) have reviewed the literature and recommended a value of $\alpha_{\mathrm{abs}}=7.5 \pm 1.2 \mathrm{~m}^{2} \mathrm{~g}^{-1}$ for airborne, uncoated, "naked" soot particles. However, due to condensation processes and/or cloud processing, atmospheric soot particles acquire non-absorbing coatings 
(mainly sulfate and/or organic carbon), which lead to absorption enhancements. Mie calculations on soot particles with sulfate coatings indicate enhancements of up to factors of 23 for extremely large coating thicknesses (corresponding to only a few mass percent of $\mathrm{C}_{\text {soot }}$ in the total aerosol) and relatively large particle size (>300 nm) (Martins et al., 1998a; Fuller et al., 1999). This is consistent with recent measurements by Schnaiter et al. (2005a) that showed enhancement factors of up to $2.0 \pm 0.2$ for $400 \mathrm{~nm}$ (diesel) soot particles coated by organic carbon $\left(\mathrm{C}_{\text {soot }}\right.$ volume fraction $\left.<3 \%\right)$. In addition, hygroscopic particle growth may further enhance $\alpha_{\text {abs }}$ by up to a factor of about 1.3 at relative humidities up to 95\% (Redemann et al., 2001). Hence, for atmospheric conditions we expect $\alpha_{\mathrm{abs}}=7.5 \pm 1.2 \mathrm{~m}^{2} \mathrm{~g}^{-1}$ only to be realistic in near-source regimes; aged soot particles may exceed this value by a factor 2 or more.

For filter-based $\mathrm{BC}_{\mathrm{e}}$ methods, one can either convert the measured attenuation into absorption (as described above) and then apply $\alpha_{\mathrm{abs}}$, or apply the attenuation cross section $\left(\alpha_{\mathrm{ATN}}\right)$ directly to the attenuation coefficient. In practice, a value of about $10 \mathrm{~m}^{2} \mathrm{~g}^{-1}$ is typically used to derive $\mathrm{BC}_{\mathrm{e}}$ from absorption measurements. However, the range of values for $\alpha_{\text {ATN }}$ reported in the literature is between about 1 to $30 \mathrm{~m}^{2} \mathrm{~g}^{-1}$ (Liousse et al., 1993; Chylek et al., 1995; Liousse et al., 1995; Colbeck et al., 1997; Petzold et al., 1997; Martins et al., 1998a; Moosmüller et al., 1998; Reid et al., 1998a; Fuller et al., 1999; Kopp et al., 1999; Lavanchy et al., 1999; Dillner et al., 2001; Sharma et al., 2002; Lim et al., 2003; Schnaiter et al., 2003). This range is so large because, in addition to the inherent variability of $\alpha_{\mathrm{abs}}, \alpha_{\mathrm{ATN}}$ is affected by experimental bias. Since $\alpha_{\mathrm{ATN}}$ is determined as the ratio between $\alpha_{\mathrm{abs}}$ and $\mathrm{C}_{\mathrm{soot}}$, it contains the numerous instrumentspecific uncertainties of $\alpha_{\mathrm{abs}}$ that depend on aerosol properties such as chemical composition, particle size and shape, and mixing state, as well as biases related to the measurement of $\mathrm{C}_{\mathrm{soot}}$, usually determined by thermochemical techniques with all the problems discussed in Sect. 2.1. Theoretical considerations as well as laboratory experiments show that, even with the same instrumental setup, $\alpha_{\mathrm{ATN}}$ varies considerably as a function of the LAC content of the aerosol, and becomes most variable and uncertain for aerosol with low LAC fractions, in the range commonly encountered in non-urban and remote regions (Horvath, 1997; Lindberg et al., 1999). These problems increase toward lower wavelengths, and therefore most strongly influence measurements made with instruments using green light (e.g., the PSAP at $565 \mathrm{~nm}$ ) or the shorter-wavelength channels of the 7-wavelength aethalometer AE-31. The aethalometer model AE10, which uses white light at an effective wavelength of $880 \mathrm{~nm}$ (Weingartner et al., 2003) is likely to be less affected.

The fact that $\alpha_{\text {ATN }}$ is usually derived from thermochemical EC $\mathrm{E}_{\mathrm{a}}$ measurements is probably one of the primary causes for the huge variations in $\alpha_{\text {ATN }}$ observed in calibration studies. In most cases, the importance of this source of uncertainty was, however, not appreciated by the authors, and the relative variations of $\alpha_{\mathrm{ATN}}$ were often explained as resulting only from differences in morphology and mixing state of LAC related to different sources and aging processes. It can therefore be concluded that, even if the only absorbing substance in aerosols were $\mathrm{C}_{\text {soot }}$, an uncertainty of about a factor of two in the estimation of "BC" would result from the variability of $\alpha_{\mathrm{ATN}}$ itself. A good example for this is the study by Lim et al. (2003) where $\mathrm{BC}_{\mathrm{e}}$ concentrations differing by a factor of two were reported by an aethalometer and a PSAP running in parallel at the same site, in spite of the fact that the two instruments are using essentially the same measurement principle.

\subsubsection{Problems related to the presence of $\mathrm{C}_{\text {brown }}$}

One would expect that optical measurements of $\mathrm{BC}_{\mathrm{e}}$ by, e.g., an aethalometer or PSAP, are less affected by the presence of $\mathrm{C}_{\text {brown }}$ than thermochemical methods. This is because a typical absorption spectrum of HULIS shows a steep decrease of absorbance into the visible (Havers et al., 1998b; Zappoli et al., 1999; Hoffer et al., 2005), and has a very low specific absorption $\left(<0.05 \mathrm{~m}^{2} \mathrm{~g}^{-1}\right)$ at the operational wavelengths of these instruments (535 and $550 \mathrm{~nm}$, respectively). It should be noted that in the accumulation mode (diameters $100-1000 \mathrm{~nm}$ ), where the mass concentration of water soluble HULIS is highest (Lukács et al., 2004), Mie theory predicts that even spherical particles of pure graphite would have a significantly lower mass absorption efficiency than those in the Aitken mode (diameter $<100 \mathrm{~nm}$ ). These two effects combined make it probable that over most of the troposphere, the contribution of $\mathrm{C}_{\text {brown }}$ to atmospheric light absorption relative to that of $\mathrm{C}_{\mathrm{soot}}$ will be rather low in the wavelength range of $500-550 \mathrm{~nm}$. However, given the strongly skewed absorption of $\mathrm{C}_{\text {brown }}$ towards the $\mathrm{UV}$, this statement may not be true for atmospheric light absorption integrated over the solar spectrum, i.e., the flux of energy that is absorbed in the troposphere (Hoffer et al., 2005). The possible consequences of this wavelength dependence will be discussed in detail in Sect. 3.

The 7- $\lambda$ Aethalometer (Model E31, 450 to $950 \mathrm{~nm}$ ) tries to capitalize on the difference in spectral dependence of $\mathrm{C}_{\text {brown }}$ and $\mathrm{C}_{\text {soot }}$ by measuring $\mathrm{C}_{\text {soot }}$ in the near-infrared regime and deriving $\mathrm{C}_{\text {brown }}$ from a near-UV channel after subtracting the $\mathrm{C}_{\text {soot }}$ absorption component, assuming a $\lambda^{-1}$ dependence for $\mathrm{C}_{\mathrm{soot}}$ absorption. A similar approach has been proposed by Kirchstetter et al. (2004). However, in addition to the numerous systematic uncertainties associated with most filterbased sampling techniques, this concept assumes that the optical properties of $\mathrm{C}_{\text {brown }}$ are fairly constant. As illustrated in Fig. 1, this cannot be expected due to the variable chemical nature of $\mathrm{C}_{\text {brown }}$ in general and, for biomass burning in particular, due to the dependence of the optical properties of hydrogenated carbon on the encountered thermal annealing temperatures (Smith, 1984). The situation is further complicated by the presence of non-carbonaceous absorbing aerosol 
components such as soil dust (mainly hematite), which can play a significant role even in locations quite distant from desert regions (Fialho et al., 2005).

We conclude that, because of the problems related to aerosol/filter interactions, uncertainties in the mass absorption coefficient, and the different spectral properties of $\mathrm{C}_{\mathrm{soot}}$ and $\mathrm{C}_{\text {brown }}$, a unique relationship between light absorption and "black carbon" cannot be expected to exist (Lindberg et al., 1999). This is the reason why we have introduced the term "equivalent black carbon", $\mathrm{BC}_{\mathrm{e}}$, which is that amount of $\mathrm{C}_{\text {soot }}$ that would cause the same amount of light absorption as that observed in the sample, using the value of $\alpha_{\mathrm{ATN}}$ and correction factors applied with a particular instrument. More fundamentally, the whole concept of determining a single value of "black carbon" from an absorption measurement on biomass smoke (and presumably also any aerosol sample that contains $\mathrm{C}_{\text {brown }}$ ) must be called into question. Since a given sample consists of a mixture of $\mathrm{C}_{\text {soot }}$ and $\mathrm{C}_{\text {brown }}$ in unknown proportions, and both components have different ratios of light absorption to carbon mass, a unique value of "BC" mass concentration cannot be derived from light absorption. The errors related to the presence of $\mathrm{C}_{\text {brown }}$ can be reduced significantly by making the absorption measurements at higher wavelengths (red light), where $\mathrm{C}_{\text {brown }}$ absorbs only very weakly. Even more information can be gained by making absorption measurements across the visible spectrum, which provides a possibility to determine separately the contributions from $\mathrm{C}_{\text {soot }}$ and $\mathrm{C}_{\text {brown }}$ (see Sect. 3).

\section{Wavelength dependence of absorption and its possible effect on tropospheric photochemistry}

Light absorption by particles is often measured at only one wavelength, and is extrapolated to other wavelengths using the power-law relationship for the spectral dependence of absorption:

$\alpha_{\mathrm{abs}}=K \times \lambda^{-\stackrel{\circ}{\mathrm{abs}}}$

where $\alpha_{\text {abs }}$ is the mass absorption efficiency of the particles $\left(\mathrm{m}^{2} \mathrm{~g}^{-1}\right), K$ is a constant that includes the aerosol mass concentration, $\lambda(\mathrm{nm})$ is the wavelength of the light, and $\AA_{\text {abs }}$ is the Ångström exponent for absorption. Although there is no theoretical justification for this equation, it generally adequately describes spectral absorption of atmospheric aerosol from the near UV to the near infrared regime. For small spherical particles $(2 r \pi|m| / \lambda \ll 1)$ with radius $\mathrm{r}$ and wavelength independent refractive index $\mathrm{m}, \AA_{\text {abs }}$ equals to 1.0 (Bond, 2001). For reasonable particle size distributions and a LAC refractive index of $m=1.55-0.5 i$, the theoretical values of $\AA$ typically varies between 0.2 and 1.2. Measurements confirm that $\AA_{\text {abs }}$ values are close to 1 in aerosols in which pure $\mathrm{C}_{\text {soot }}$ dominates the LAC, as has been shown by several authors for motor vehicle emissions and urban aerosols by in-situ measurements (Rosen et al., 1978; Horvath, 1997;
Bergstrom et al., 2002; Schnaiter et al., 2003; Lawless et al., 2004; Bond and Bergstrom, 2006) and inversion of remote sensing data (Dubovik et al., 1998; Bergstrom et al., 2003).

When absorption is stronger at shorter wavelengths, i.e., the particles appear brownish or yellow, $\AA$ will be significantly greater than unity. Values of 2.0 and more were found in aerosol collected near a lignite combustion plant (Bond et al., 1999b), in biomass smoke (Kirchstetter et al., 2004; Schmid et al., 2005; Schnaiter et al., 2005b), environmental tobacco smoke (Lawless et al., 2004), rural aerosol (Lindberg et al., 1993), and in particles produced by oxygen-deficient combustion of propane (Schnaiter et al., 2006). The highest values of $\AA$ are found for the yellowish to brownish products of pure smoldering combustion, e.g., tobacco smoke (3.5, Lawless et al., 2004) or water-soluble HULIS from biomass burning (6-7, Hoffer et al., 2005). This steepening of the increase of absorption towards shorter wavelengths can be attributed to the presence of significant amounts of lightabsorbing organic compounds, i.e., $\mathrm{C}_{\text {brown }}$, in aerosols resulting from low-temperature combustion (Bond, 2001). The different spectral behavior of $\mathrm{C}_{\text {soot }}$ and $\mathrm{C}_{\text {brown }}$ can be used to separate their contributions to light absorption by aerosols. Kirchstetter et al. (2004) have proposed that absorption spectra of mixed aerosols can be deconvoluted into a component resulting from $\mathrm{C}_{\text {soot }}$ (assuming that its spectral properties are constant and well known) and a component attributable to $\mathrm{C}_{\text {brown }}$ (with less well defined and variable spectral behavior). This is a very promising approach, and if validated and used with a larger data set, it might open up the possibility to asses the role of $\mathrm{C}_{\text {brown }}$ in atmospheric light absorption.

The different spectral dependence of light absorption by $\mathrm{C}_{\text {soot }}$ and $\mathrm{C}_{\text {brown }}$ means that caution must be exercised when extrapolating absorption measured at a single wavelength over the solar spectrum, especially when the mass concentration of $\mathrm{C}_{\text {soot }}$ is low relative to that of $\mathrm{C}_{\text {brown. When }} \mathrm{ab}$ sorption coefficients are measured at wavelengths in the middle and upper parts of the visible spectrum and the spectral properties of $\mathrm{C}_{\text {soot }}$ are assumed to represent all ambient lightabsorbing carbon, the reduction of downward UV irradiance may be significantly underestimated. Since UV irradiance plays a very important role in tropospheric ozone production and photochemistry in general, its erroneous assessment through oversimplified interpretation of "BC" data may considerably weaken our ability to understand and predict photochemical processes in the troposphere (Albuquerque et al., 2005).

The first explanation for the reduced downward UVirradiance observed in urban areas was provided by Jacobson (1999) who attributed it to UV-absorbing organic species such as nitrated aromatics, benzaldehydes, benzoic acids, polycyclic aromatic hydrocarbons, and to a lesser extent, nitrated inorganic compounds. In particular, nitrated aromatic compounds, PAHs and benzaldehydes were found to be the most effective UV-A and UV-B absorbers in terms of their imaginary refractive indices and absorption wavelengths. 
These compounds indeed show very strong wavelength dependence, and because their absorption tails off between the UV and visible wavelengths, global UV irradiance is attenuated much more than total solar irradiance. The decreased UV flux was calculated to reduce ozone mixing ratios in Los Angeles by $5-8 \%$. Model column simulations with the inclusion of enhanced aerosol absorption, however, still overpredicted the observed UV irradiance by 8 and $25 \%$ for an urban and rural site, respectively. The absorption by organic aerosol represented about $\frac{1}{4}$ of the total downward UV attenuation, primarily due to non-nitrated and nitrated aromatic compounds in proportions of $10.2-13.5 \%$ and $8.8-14.7 \%$, respectively. In radiative transfer model calculations a positive forcing per unit mass of organic carbon of $+21 \mathrm{~W} \mathrm{~m}^{-2}$ per $\mathrm{g}$ OC was inferred from this effect alone (Jacobson, 2002).

One may speculate that the UV reduction missing from models may be due to the presence of unspeciated $\mathrm{C}_{\text {brown }}$. Its spectral properties observed in atmospheric measurements are intermediate between those of nitrated PAHs and $\mathrm{C}_{\text {soot }}$, and it shows a smooth decrease in absorbance towards the visible that can still be approximated by a power law relationship (Bond, 2001; Kirchstetter et al., 2004; Hoffer et al., 2005).

There is another property of $\mathrm{C}_{\text {brown }}$ that is worthy of note with respect to atmospheric light absorption, namely that a significant fraction of it is soluble in water (Hoffer et al., 2005). In fact, atmospheric observation on the properties of $\mathrm{C}_{\text {brown }}$ largely came from measurements of the water extract of atmospheric aerosol. Consequently, part of $\mathrm{C}_{\text {brown }}$ could dissolve into growing cloud droplets upon cloud formation and produce homogeneous absorbing droplets that affect overall cloud absorption, particularly in the UV. This effect could be most significant in clouds formed on dense biomass smoke plumes, where the concentration of $\mathrm{C}_{\text {brown }}$ can be substantial (Mayol-Bracero et al., 2002). It was calculated that, e.g., at the wavelength of $475 \mathrm{~nm}$ a hydrometeor containing $\mathrm{C}_{\text {brown }}$ at a concentration of $2 \times 10^{-6} \mathrm{M}$ absorbs about 6 times more radiation than pure water (Gelencsér et al., 2003). To the best of our knowledge, this effect has never been included in complex atmospheric radiation models.

\section{Conclusions}

The recent discovery of the widespread abundance of brown carbon in atmospheric aerosol makes it necessary to revisit the concept of a light-absorbing carbonaceous (LAC) component of atmospheric aerosol, which has been traditionally assumed to be exclusively black combustion soot $\left(\mathrm{C}_{\mathrm{soot}}\right)$. Although soot particles are readily recognizable by their typical morphologies, they are far from being uniform either in their chemical or physical properties. Unfortunately, monitoring methods that are commonly used for the determination of the mass concentration of soot carbon can only provide operationally defined quantities such as black car- bon ("BC") or elemental carbon ("EC"). However, the operational character of these analytical parameters is very often overlooked. It would therefore be highly desirable to indicate it through the use of terms like "apparent $\mathrm{EC}$ " $\left(\mathrm{EC}_{\mathrm{a}}\right)$ and "equivalent $\mathrm{BC}$ " $\left(\mathrm{BC}_{\mathrm{e}}\right)$. Even in the case of combustion soot aerosol, there is a conceptual ambiguity in the separation of organic and elemental carbon, as well as in the determination of $\mathrm{BC}_{\mathrm{e}}$ from light-absorption measurements, which introduces at least a factor-of- 2 uncertainty to their measurements. More than 50 inter-method and inter-laboratory comparisons for the determination of $\mathrm{EC}_{\mathrm{a}}$ or $\mathrm{BC}_{\mathrm{e}}$ have been conducted, showing typical differences of a factor of 2 between methods, but sometimes even discrepancies of a factor of 7 (Watson et al., 2005). In spite of this ongoing controversy and with few exceptions (e.g., Streets et al., 2001; Bond et al., 2004), "BC" is very often considered a single, well-defined and well-determined entity throughout the troposphere, especially in emission inventories, radiative transfer, and climate models, which has a uniform composition and physical properties approaching those of pure carbon black (e.g., Hansen et al., 2000; Chung and Seinfeld, 2002; Schaap et al., 2004; Wang, 2004; Hansen et al., 2005).

The presence of brown carbon $\left(\mathrm{C}_{\text {brown }}\right)$ in aerosol, for which ample evidence has recently been published, raises serious concern about this simplified approach. Here we have shown that $\mathrm{C}_{\text {brown }}$ may interfere with both $\mathrm{EC}_{\mathrm{a}}$ and $\mathrm{BC}_{\mathrm{e}}$ measurements and introduce significant bias under specific conditions. This applies in particular to any situation where light absorption is not dominated by $\mathrm{C}_{\text {soot }}$ from petroleum combustion, i.e., for regions where pyrogenic aerosols or lightabsorbing biogenic aerosols play an important role - in other words, for most of the globe outside the most highly industrialized regions.

The fact that brown carbon has progressively stronger absorption in the UV seriously calls into question whether measurements of light absorption at a single wavelength in the mid-to-upper visible can be used to infer absorption of solar radiation in the troposphere. When, for example, "BC" is determined by measurements using incandescent light dominated by the red and near-IR part of the spectrum, only the contribution from $\mathrm{C}_{\text {soot }}$ is measured, and $\mathrm{C}_{\text {brown }}$ remains "invisible". If such "BC" data are subsequently used to asses the climate effects of light-absorbing aerosols (and this "BC" is assumed to have the spectral properties of $\mathrm{C}_{\text {soot }}$ ), the contribution of $\mathrm{C}_{\text {brown }}$ is lost. Consequently, representative measurements of the spectral mass absorption efficiency of $\mathrm{C}_{\text {brown }}$ and its abundance in the global atmosphere must be accomplished, so that its contribution to atmospheric light absorption can be evaluated. In the light of these findings, even the concept of "BC" as a conservative atmospheric tracer for combustion processes must be challenged.

At the same time, further studies are needed on the properties and origin of chromophoric organic species to establish the role they play in the global troposphere. Eventually, the whole concept of "light- absorbing carbon", and the 
analytical methods used, need to be carefully reconsidered and "standardized" to provide reliable input for atmospheric models and legislative measures. Novel measurement techniques, such as the use of fluorescence lidar (Immler et al., 2005), spectral absorption measurements (Kirchstetter et al., 2004), and Electrospray Ionization Fourier Transform Ion Cyclotron Resonance Mass Spectrometry (FT-ICR MS) (Kramer et al., 2004), will have to be applied to determine the concentrations, distribution and properties of $\mathrm{C}_{\text {brown }}$. The development and widespread use of standard reference materials, such as RM 8785 (Air Particulate Matter on Filter Media) (Klouda et al., 2005) is encouraged.

We conclude that, at the present state of the art, the uncertainties and potential biases in $\mathrm{EC}_{\mathrm{a}}$ and $\mathrm{BC}_{\mathrm{e}}$ measurements are large, and that there is a poor correlation between measured $\mathrm{EC}_{\mathrm{a}}$ or $\mathrm{BC}_{\mathrm{e}}$ values and atmospheric light absorption. If these errors are systematic, and unless there is some degree of fortuitous compensation between upward and downward biases, they could call into question even the sign of the direct forcing of anthropogenic aerosols on climate!

Acknowledgements. We thank T. W. Andreae, D. Chand, A. Hoffer, O. Schmid, and U. Pöschl for helpful comments and discussions. We very much appreciate the detailed and thoughtful comments by reviewer T. Bond.

Edited by: Y. Rudich

\section{References}

Abel, S. J., Haywood, J. M., Highwood, E. J., Li, J., and Busek, P. R.: Evolution of aerosol properties from biomass burning measured during SAFARI 2000, Geophys. Res. Lett., 30, 1783, doi:10.1029/2003GL017342, 2003.

Akhter, M. S., Chughtai, A. R., and Smith, D. M.: The structure of hexane soot - I. Spectroscopic studies, Appl. Spectrosc., 39, 143-153, 1985.

Albuquerque, L. M. M., Longo, K. M., Freitas, S. R., Tarasova, T., Plana Fattori, A., Nobre, C., and Gatti, L. V.: Sensitivity studies on the photolysis rates calculation in Amazonian atmospheric chemistry - Part I: The impact of the direct radiative effect of biomass burning aerosol particles, Atmos. Chem. Phys. Discuss., 5, 9325-9353, 2005,

http://www.atmos-chem-phys-discuss.net/5/9325/2005/.

Andreae, M. O.: Soot carbon and excess fine potassium: Longrange transport of combustion-derived aerosols, Science, 220, 1148-1151, 1983.

Andreae, M. O.: Climatic effects of changing atmospheric aerosol levels, in: World Survey of Climatology, Future Climates of the World, edited by: Henderson-Sellers, A., Elsevier, Amsterdam, Vol. 16, pp. 341-392, 1995.

Andreae, M. O., Andreae, T. W., Ferek, R. J., and Raemdonck, H.: Long-range transport of soot carbon in the marine atmosphere, Science of the Total Environment, 36, 73-80, 1984.

Andreae, M. O. and Crutzen, P. J.: Atmospheric aerosols: Biogeochemical sources and role in atmospheric chemistry, Science, 276, 1052-1056, 1997.
Andreae, M. O., Rosenfeld, D., Artaxo, P., Costa, A. A., Frank, G. P., Longo, K. M., and Silva-Dias, M. A. F.: Smoking rain clouds over the Amazon, Science, 303, 1337-1342, 2004.

Arnott, W. P., Hamasha, K., Moosmüller, H., Sheridan, P. J., and Ogren, J. A.: Towards aerosol light-absorption measurements with a 7-wavelength Aethalometer: Evaluation with a photoacoustic instrument and 3-wavelength nephelometer, Aerosol Sci. Tech., 39, 17-29, 2005.

Arnott, W. P., Moosmüller, H., Rogers, C. F., Jin, T., and Bruch, R.: Photoacoustic spectrometer for measuring light absorption by aerosol: Instrument description, Atmos. Environ., 33, 28452852, 1999.

Arnott, W. P., Moosmüller, H., Sheridan, P. J., Ogren, J. A., Raspet, R., Slaton, W. V., Hand, J. L., Kreidenweis, S. M., and Collett, J.: Photoacoustic and filter-based ambient aerosol light absorption measurements: Instrument comparisons and the role of relative humidity, J. Geophys. Res., 108, 4034, doi:10.1029/2002JD002165, 2003.

Bank, S. and Castillo, R.: Analysis of organic matter from cloud particles, Geophys. Res. Lett., 14, 210-212, 1987.

Bergstrom, R. W., Pilewskie, P., Schmid, B., and Russell, P. B.: Estimates of the spectral aerosol single scattering albedo and aerosol radiative effects during SAFARI 2000, J. Geophys. Res., 108, 8474, doi:10.1029/2002JD002435, 2003.

Bergstrom, R. W., Russell, P. B., and Hignett, P.: Wavelength dependence of the absorption of black carbon particles: Predictions and results from the TARFOX experiment and implications for the aerosol single scattering albedo, J. Atmos. Sci., 59, 567-577, 2002.

Birch, M. E. and Cary, R. A.: Elemental carbon-based method for monitoring occupational exposures to particulate diesel exhaust, Aerosol Sci. Tech., 25, 221-241, 1996.

Bockhorn, H. (Ed.): Soot Formation in Combustion: Mechanisms and Models, Berlin \& New York, Springer-Verlag, 596 p., 1994.

Bodhaine, B. A.: Aerosol absorption measurements at Barrow, Mauna Loa and the South Pole, J. Geophys. Res., 100, 89678975, 1995.

Bond, T. C.: Spectral dependence of visible light absorption by carbonaceous particles emitted from coal combustion, Geophys. Res. Lett., 28, 4075-4078, 2001.

Bond, T. C., Anderson, T. L., and Campbell, D.: Calibration and intercomparison of filter-based measurements of visible light absorption by aerosols, Aerosol Sci. Tech., 30, 582-600, 1999a.

Bond, T. C. and Bergstrom, R. W.: Light absorption by carbonaceous particles: An investigative review, Aerosol Sci. Tech., 40, 27-67, 2006.

Bond, T. C., Bussemer, M., Wehner, B., Keller, S., Charlson, R. J., and Heintzenberg, J.: Light absorption by primary particle emissions from a lignite burning plant, Environ. Sci. Technol., 33, 3887-3891, 1999 b.

Bond, T. C., Charlson, R. J., and Heintzenberg, J.: Quantifying the emission of light-absorbing particles: Measurements tailored to climate studies, Geophys. Res. Lett., 25, 337-340, 1998.

Bond, T. C., Streets, D. G., Yarber, K. F., Nelson, S. M., Woo, J. H., and Klimont, Z.: A technology-based global inventory of black and organic carbon emissions from combustion, J. Geophys. Res., 109, D14203, doi:10.1029/2003JD003697, 2004. 
Bond, T. C. and Sun, H. L.: Can reducing black carbon emissions counteract global warming?, Environ. Sci. Technol., 39, 59215926, 2005.

Brimblecombe, P.: The big smoke : a history of air pollution in London since medieval times, London, New York, Methuen, 185 p., 1987.

Buseck, P. R., Huang, B. J., and Keller, L. P.: Electron-microscope investigation of the structures of annealed carbons, Energy \& Fuels, 1, 105-110, 1987.

Cachier, H., Brémond, M.-P., and Buat-Ménard, P.: Carbonaceous aerosols from different tropical biomass burning sources, Nature, 340, 371-373, 1989a.

Cachier, H., Brémond, M. P., and Buat-Ménard, P.: Thermal separation of soot carbon, Aerosol Sci. Tech., 10, 358-364, 1989b.

Cadle, S. H., Groblicki, P. J., and Mulawa, P. A.: Problems in the sampling and analysis of carbon particulate, Atmos. Environ., 17, 593-600, 1983.

Chang, S. G., Brodzinsky, R., Gundel, L. A., and Novakov, T.: Chemical and catalytic properties of elemental carbon, in: Particulate Carbon: Atmospheric Life Cycle, edited by: Wolff, G. T.,and Klimisch, R. L., Plenum Press, New York, pp. 159-181, 1982.

Chen, L. W. A., Chow, J. C., Watson, J. G., Moosmüller, H., and Arnott, W. P.: Modeling reflectance and transmittance of quartzfiber filter samples containing elemental carbon particles: Implications for thermal/optical analysis, J. Aerosol Sci., 35, 765-780, 2004.

Chow, J. C., Watson, J. G., Chen, L. W. A., Arnott, W. P., and Moosmüller, H.: Equivalence of elemental carbon by thermal/optical reflectance and transmittance with different temperature protocols, Environ. Sci. Technol., 38, 4414-4422, 2004.

Chow, J. C., Watson, J. G., Crow, D., Lowenthal, D. H., and Merrifield, T.: Comparison of IMPROVE and NIOSH carbon measurements, Aerosol Sci. Tech., 34, 23-34, 2001.

Chow, J. C., Watson, J. G., Pritchett, L. C., Pierson, W. R., Frazier, C. A., and Purcell, R. G.: The DRI thermal-optical reflectance carbon analysis system - Description, evaluation and applications in United States air quality studies, Atmos. Environ., 27A, 11851201, 1993.

Chughtai, A. R., Kim, J. M., and Smith, D. M.: The effect of air/fuel ratio on properties and reactivity of combustion soots, J. Atmos. Chem., 43, 21-43, 2002.

Chung, S. H. and Seinfeld, J. H.: Global distribution and climate forcing of carbonaceous aerosols, J. Geophys. Res., 107, 4407, doi:10.1029/2001JD001397, 2002.

Chung, S. H. and Seinfeld, J. H.: Climate response of direct radiative forcing of anthropogenic black carbon, J. Geophys. Res., 110, D11102, doi:10.1029/2004JD005441, 2005.

Chylek, P., Videen, G., Ngo, D., Pinnick, R. G., and Klett, J. D.: Effect of black carbon on the optical properties and climate forcing of sulfate aerosols, J. Geophys. Res., 100, 16325-16332, 1995.

Clague, A. D. H., Donnet, J., Wang, T. K., and Peng, J. C. M.: A comparison of diesel engine soot with carbon black, Carbon, 37 , 1553-1565, 1999.

Colbeck, I., Appleby, L., Hardman, E. J., and Harrison, R. M.: The optical properties and morphology of cloud-processed carbonaceous smoke, J. Aerosol Sci., 21, 527-538, 1990.

Colbeck, I., Atkinson, B., and Johar, Y.: The morphology and optical properties of soot produced by different fuels, J. Aerosol Sci.,
28, 715-723, 1997.

Conny, J. M., Klinedinst, D. B., Wight, S. A., and Paulsen, J. L.: Optimizing thermal-optical methods for measuring atmospheric elemental (black) carbon: A response surface study, Aerosol Sci. Tech., 37, 703-723, 2003.

Countess, R. J.: Interlaboratory analyses of carbonaceous aerosol samples, Aerosol Sci. Tech., 12, 114-121, 1990.

Decesari, S., Facchini, M. C., Matta, E., Lettini, F., Mircea, M., Fuzzi, S., Tagliavini, E., and Putaud, J. P.: Chemical features and seasonal variation of fine aerosol water-soluble organic compounds in the Po Valley, Italy, Atmos. Environ., 35, 3691-3699, 2001.

Decesari, S., Fuzzi, S., Facchini, M. C., et al.: Characterization of the organic composition of aerosols from Rondônia, Brazil, during the LBA-SMOCC 2002 experiment and its representation through model compounds, Atmos. Chem. Phys., 6, 375-402, 2006, http://www.atmos-chem-phys.net/6/375/2006/.

Dillner, A. M., Stein, C., Larson, S. M., and Hitzenberger, R.: Measuring the mass extinction efficiency of elemental carbon in rural aerosol, Aerosol Sci. Tech., 35, 1009-1021, 2001.

Dubovik, O., Holben, B. N., Kaufman, Y. J., Yamasoe, M., Smirnov, A., Tanre, D., and Slutsker, I.: Single-scattering albedo of smoke retrieved from the sky radiance and solar transmittance measured from ground, J. Geophys. Res., 103, 31 903-31 923, 1998.

Ebert, L. B.: Is soot composed predominantly of carbon clusters?, Science, 247, 1468-1471, 1990.

Ellis, E. C. and Novakov, T.: Application of thermal analysis to the characterization of organic aerosol particles, Science of the Total Environment, 23, 227-238, 1982.

Ferry, D., Suzanne, J., Nitsche, S., Popovitcheva, O. B., and Shonija, N. K.: Water adsorption and dynamics on kerosene soot under atmospheric conditions, J. Geophys. Res., 107, 4734, doi:10.1029/2002JD002459, 2002.

Fialho, P., Hansen, A. D. A., and Honrath, R. E.: Absorption coefficients by aerosols in remote areas: a new approach to decouple dust and black carbon absorption coefficients using sevenwavelength Aethalometer data, J. Aerosol Sci., 36, 267-282, 2005.

Fuller, K. A., Malm, W. C., and Kreidenweis, S. M.: Effects of mixing on extinction by carbonaceous particles, J. Geophys. Res., 104, 15 941-15 954, 1999.

Fuzzi, S., Decesari, S., Facchini, M. C., Matta, E., Mircea, M., and Tagliavini, E.: A simplified model of the water soluble organic component of atmospheric aerosols, Geophys. Res. Lett., 28, 4079-4082, 2001.

Gelencsér, A., Hoffer, A., Kiss, G., Tombácz, E., Kurdi, R., and Bencze, L.: In-situ formation of light-absorbing organic matter in cloud water, J. Atmos. Chem., 45, 25-33, 2003.

Gelencsér, A., Hoffer, A., Molnár, A., Krivácsy, Z., Kiss, G., and Mészáros, E.: Thermal behaviour of carbonaceous aerosol from a continental background site, Atmos. Environ., 34, 823-831, 2000a.

Gelencsér, A., Mészáros, T., Blazsó, M., Kiss, G., Krivácsy, Z., Molnár, A., and Mészáros, E.: Structural characterisation of organic matter in fine tropospheric aerosol by pyrolysis-gas chromatography-mass spectrometry, J. Atmos. Chem., 37, 173183, 2000b.

Goldberg, E. D.: Black Carbon in the Environment: Properties and 
Distribution, New York, J. Wiley \& Sons, 198 p., 1985.

Graber, E. R. and Rudich, Y.: Atmospheric HULIS: How humiclike are they? A comprehensive and critical review, Atmos. Chem. Phys., 6, 729-753, 2006, http://www.atmos-chem-phys.net/6/729/2006/.

Grieco, W. J., Howard, J. B., Rainey, L. C., and Vander Sande, J. B.: Fullerenic carbon in combustion-generated soot, Carbon, 38, 597-614, 2000

Grisdale, R. O.: The formation of black carbon, J. Appl. Phys., 24, 1082-1091, 1953.

Guillemin, M., Cachier, H., Chini, C., Dabill, D., Dahmann, D., Diebold, F., Fischer, A., Fricke, H. H., Groves, J. A., Hebisch, R., Houpillart, M., Israel, G., Mattenklott, M., Moldenhauer, W., Sandino, J. P., Schlums, C., Sutter, E., and Tucek, E.: International round robin tests on the measurement of carbon in diesel exhaust particulates, International Archives of Occupational and Environmental Health, 70, 161-172, 1997.

Gundel, L. A., Dod, R. L., Rosen, H., and Novakov, T.: The relationship between optical attenuation and black carbon concentration for ambient and source particles, Science of the Total Environment, 36, 197-202, 1984.

Gustafsson, O., Bucheli, T. D., Kukulska, Z., Andersson, M., Largeau, C., Rouzaud, J. N., Reddy, C. M., and Eglinton, T. I.: Evaluation of a protocol for the quantification of black carbon in sediments, Global Biogeochem. Cycles, 15, 881-890, 2001.

Hansen, A. D. A., Rosen, H., and Novakov, T.: The aethalometer - an instrument for the real-time measurement of optical absorption by aerosol particles, Science of the Total Environment, 36, 191-196, 1984.

Hansen, J., and Nazarenko, L.: Soot climate forcing via snow and ice albedos, Proc. Natl. Acad. Sci. USA, 101, 423-428, 2004.

Hansen, J., Sato, M., Ruedy, R., Lacis, A., and Oinas, V.: Global warming in the twenty-first century: An alternative scenario, Proc. Natl. Acad. Sci. USA, 97, 9875-9880, 2000.

Hansen, J., Sato, M., Ruedy, R., et al.: Efficacy of Climate Forcings, J. Geophys. Res., 110, D18104, doi:10.1029/2005JD005776, 2005.

Hansen, J. E., Sato, M., Lacis, A., Ruedy, R., Tegen, I., and Matthews, E.: Climate forcings in the industrial era, Proc. Natl. Acad. Sci. USA, 95, 12 753-12 758, 1998.

Havers, N., Burba, P., Klockow, D., and Klockow-Beck, A.: Characterization of humic-like substances in airborne particulate matter by capillary electrophoresis, Chromatographia, 47, 619-624, 1998a.

Havers, N., Burba, P., Lambert, J., and Klockow, D.: Spectroscopic characterization of humic-like substances in airborne particulate matter, J. Atmos. Chem., 29, 45-54, 1998b.

Hegglin, M. I., Krieger, U. K., Koop, T., and Peter, T.: Organicsinduced fluorescence in Raman studies of sulfuric acid aerosols, Aerosol Sci. Tech., 36, 510-512, 2002.

Heintzenberg, J.: Size-segregated measurements of particulate elemental carbon and aerosol light absorption at remote locations, Atmos. Environ., 16, 2461-2469, 1982.

Heintzenberg, J.: A processor-controlled multisample soot photometer, Aerosol Sci. Tech., 8, 227-233, 1988.

Hitzenberger, R., Jennings, S. G., Larson, S. M., Dillner, A., Cachier, H., Galambos, Z., Rouc, A., and Spain, T. G.: Intercomparison of measurement methods for black carbon aerosols, Atmos. Environ., 33, 2823-2833, 1999.
Hoffer, A., Gelencsér, A., Guyon, P., Kiss, G., Schmid, O., Frank, G., Artaxo, P., and Andreae, M. O.: Optical properties of humiclike substances (HULIS) in biomass-burning aerosols, Atmos. Chem. Phys. Discuss., 5, 7341-7360, 2005, http://www.atmos-chem-phys-discuss.net/5/7341/2005/.

Horvath, H.: Experimental calibration for aerosol light absorption measurements using the integrating plate method - Summary of the data, J. Aerosol Sci., 28, 1149-1161, 1997.

Huebert, B. J. and Charlson, R. J.: Uncertainties in data on organic aerosols, Tellus Series B-Chemical and Physical Meteorology, 52, 1249-1255, 2000.

Huffman, H. D.: Comparison of the light absorption coefficient and carbon measures for remote aerosols: An independent analysis of data from the IMPROVE Network - I, Atmos. Environ., 30, 73-83, 1996a.

Huffman, H. D.: The reconstruction of aerosol light absorption by particle measurements at remote sites: An independent analysis of data from the IMPROVE Network - II, Atmos. Environ., 30, 85-99, 1996b.

Immler, F., Engelbart, D., and Schrems, O.: Fluorescence from atmospheric aerosol detected by a lidar indicates biogenic particles in the lowermost stratosphere, Atmos. Chem. Phys., 5, 345-355, 2005 , http://www.atmos-chem-phys.net/5/345/2005/.

Jacobson, M. Z.: Isolating nitrated and aromatic aerosols and nitrated aromatic gases as sources of ultraviolet light absorption, J. Geophys. Res., 104, 3527-3542, 1999.

Jacobson, M. Z.: Global direct radiative forcing due to multicomponent anthropogenic and natural aerosols, J. Geophys. Res., 106, 1551-1568, 2001.

Jacobson, M. Z.: Control of fossil-fuel particulate black carbon and organic matter, possibly the most effective method of slowing global warming, J. Geophys. Res., 107, 4410, doi:10.1029/2001JD001376, 2002.

Jacobson, M. Z.: Climate response of fossil fuel and biofuel soot, accounting for soot's feedback to snow and sea ice albedo and emissivity, J. Geophys. Res., 109, D21201, doi:10.1029/2004JD004945, 2004.

Jones, G. S., Jones, A., Roberts, D. L., Stott, P. A., and Williams, K. D.: Sensitivity of global-scale climate change attribution results to inclusion of fossil fuel black carbon aerosol, Geophys. Res. Lett., 32, L14701, doi:10.1029/2005GL023370, 2005.

Kim, S., Kramer, R. W., and Hatcher, P. G.: Graphical method for analysis of ultrahigh-resolution broadband mass spectra of natural organic matter, the van Krevelen diagram, Anal. Chem., 75, 5336-5344, 2003.

Kim, S. W., Kaplan, L. A., Benner, R., and Hatcher, P. G.: Hydrogen-deficient molecules in natural riverine water samples evidence for the existence of black carbon in DOM, Mar. Chem., 92, 225-234, 2004.

Kirchstetter, T. W., Novakov, T., and Hobbs, P. V.: Evidence that the spectral dependence of light absorption by aerosols is affected by organic carbon, J. Geophys. Res., 109, D21208, doi:10.1029/2004JD0004999, 2004.

Kirchstetter, T. W., Novakov, T., Hobbs, P. V., and Magi, B.: Airborne measurements of carbonaceous aerosols in southern Africa during the dry, biomass burning season, J. Geophys. Res., 108, doi:10.1029/2002JD002171, 2003.

Kiss, G., Varga, B., Gelencsér, A., Krivácsy, Z., Molnár, A., Als- 
berg, T., Persson, L., Hansson, H. C., and Facchini, M. C.: Characterisation of polar organic compounds in fog water, Atmos. Environ., 35, 2193-2200, 2001.

Klouda, G. A., Filliben, J. J., Parish, H. J., Chow, J. J., Watson, J. G., and Cary, R. A.: Reference material 8785: Air particulate matter on filter media, Aerosol Sci. Tech., 39, 173-183, 2005.

Kopp, C., Petzold, A., and Niessner, R.: Investigation of the specific attenuation cross-section of aerosols deposited on fiber filters with a polar photometer to determine black carbon, J. Aerosol Sci., 30, 1153-1163, 1999.

Kramer, R. W., Kujawinski, E. B., and Hatcher, P. G.: Identification of black carbon derived structures in a volcanic ash soil humic acid by Fourier transform ion cyclotron resonance mass spectrometry, Environ. Sci. Technol., 38, 3387-3395, 2004.

Krivácsy, Z., Gelencsér, A., Kiss, G., Mészáros, E., Molnár, A., Hoffer, A., Mészáros, T., Sárvári, Z., Temesi, D., Varga, B., Baltensperger, U., Nyeki, S., and Weingartner, E.: Study on the chemical character of water soluble organic compounds in fine atmospheric aerosol at the Jungfraujoch, J. Atmos. Chem., 39, 235-259, 2001.

Krivácsy, Z., Kiss, G., Varga, B., Galambos, I., Sárvári, Z., Gelencsér, A., Molnár, A., Fuzzi, S., Facchini, M. C., Zappoli, S., Andracchio, A., Alsberg, T., Hansson, H. C., and Persson, L.: Study of humic-like substances in fog and interstitial aerosol by size-exclusion chromatography and capillary electrophoresis, Atmos. Environ., 34, 4273-4281, 2000.

Kuhlbusch, T. A. J., Hertlein, A. M., and Schütz, L. W.: Sources, determination, monitoring, and transport of carbonaceous aerosols in Mainz, Germany, Atmos. Environ., 32, 10971110, 1998.

Lavanchy, V. M. H., Gaggeler, H. W., Nyeki, S., and Baltensperger, U.: Elemental carbon (EC) and black carbon (BC) measurements with a thermal method and an aethalometer at the high-alpine research station Jungfraujoch, Atmos. Environ., 33, 2759-2769, 1999.

Lawless, P. A., Rodes, C. E., and Ensor, D. S.: Multiwavelength absorbance of filter deposits for determination of environmental tobacco smoke and black carbon, Atmos. Environ., 38, 33733383, 2004.

Levin, Z. and Lindberg, J. D.: Size distributions, chemical composition, and optical properties of urban and desert aerosols in Israel, J. Geophys. Res., 84, 6941-6950, 1979.

Likens, G. E., Edgerton, E. S., and Galloway, J. N.: The composition and deposition of organic carbon in precipitation, Tellus, 35B, 16-24, 1983.

Lim, H. J., Turpin, B. J., Edgerton, E., Hering, S. V., Allen, G., Maring, H., and Solomon, P., Semicontinuous aerosol carbon measurements: Comparison of Atlanta Supersite measurements, J. Geophys. Res., 108, 8419, doi:10.1029/2001JD001214, 2003.

Limbeck, A., Kulmala, M., and Puxbaum, H.: Secondary organic aerosol formation in the atmosphere via heterogeneous reaction of gaseous isoprene on acidic particles, Geophys. Res. Lett., 30, 1996, doi:10.1029/2003GL017738, 2003.

Lin, C., and Friedlander, S. K.: A note on the use of glass fiber filters in the thermal analysis of carbon containing aerosols, Atmos. Environ., 22, 605-607, 1988.

Lindberg, J. D., Douglass, R. E., and Garvey, D. M.: Carbon and the optical properties of atmospheric dust, Appl. Opt., 32, 6077$6081,1993$.
Lindberg, J. D., Douglass, R. E., and Garvey, D. M.: Atmospheric particulate absorption and black carbon measurement, Appl. Opt., 38, 2369-2376, 1999.

Liousse, C., Cachier, H., and Jennings, S. G.: Optical and thermal measurements of black carbon aerosol content in different environments: Variation of the specific attenuation cross-section, sigma (s), Atmos. Environ., 27A, 1203-1211, 1993.

Liousse, C., Devaux, C., Dulac, F., and Cachier, H.: Aging of savanna biomass burning aerosols: Consequences on their optical properties, J. Atmos. Chem., 22, 1-17, 1995.

Lukács, H., Gelencsér, A., Pio, C., Legrand, M., Preunkert, S., Schock, M., Puxbaum, H., Kasper-Giebl, A., and Fialho, P.: Comparative study on HULIS concentrations and their seasonal variations across Europe, paper presented at: 8th International Conference on Carbonaceous Particles in the Atmosphere, Vienna, Austria, 2004.

Malm, W. C., Sisler, L. T., Kaufman, D., Eldred, R. A., and Cahill, T. A.: Spatial and seasonal trends in particle concentrations and optical extinction in the United States, J. Geophys. Res., 99, 1347-1370, 1994.

Martins, J. V., Artaxo, P., Liousse, C., Reid, J. S., Hobbs, P. V., and Kaufman, Y. J.: Effects of black carbon content, particle size, and mixing on light absorption by aerosols from biomass burning in Brazil, J. Geophys. Res., 103, 32 041-32 050, 1998a.

Martins, J. V., Hobbs, P. V., Weiss, R. E., and Artaxo, P.: Sphericity and morphology of smoke particles from biomass burning in Brazil, J. Geophys. Res., 103, 32 051-32 057, 1998 b.

Masiello, C. A.: New directions in black carbon organic geochemistry, Mar. Chem., 92, 201-213, 2004.

Mayol-Bracero, O. L., Guyon, P., Graham, B., Roberts, G., Andreae, M. O., Decesari, S., Facchini, M. C., Fuzzi, S., and Artaxo, P.: Water-soluble organic compounds in biomass burning aerosols over Amazonia: 2. Apportionment of the chemical composition and importance of the polyacidic fraction, J. Geophys. Res., 107, 8091, doi:10.1029/2001JD000522, 2002.

Medalia, A. I. and Rivin, D.: Particulate carbon and other components of soot and carbon black, Carbon, 20, 481-492, 1982.

Mertes, S., Dippel, B., and Schwarzenböck, A.: Quantification of graphitic carbon in atmospheric aerosol particles by Raman spectroscopy and first application for the determination of mass absorption efficiencies, J. Aerosol Sci., 35, 347-361, 2004.

Moosmüller, H., Arnott, W. P., and Rogers, C. F.: Methods for realtime, in situ measurement of aerosol light absorption, J. Air \& Waste Manage. Assoc., 47, 157-166, 1997.

Moosmüller, H., Arnott, W. P., Rogers, C. F., Chow, J. C., Frazier, C. A., Sherman, L. E., and Dietrich, D. L.: Photoacoustic and filter measurements related to aerosol light absorption during the Northern Front Range Air Quality Study (Colorado 1996/1997), J. Geophys. Res., 103, 28 149-28 157, 1998.

Mukai, H. and Ambe, Y.: Characterization of a humic acid-like brown substance in airborne particulate matter and tentative identification of its origin, Atmos. Environ., 20, 813-819, 1986.

Novakov, T., and Corrigan, C. E.: Thermal characterization of biomass smoke particles, Mikrochim. Acta, 119, 157-166, 1995.

Oberlin, A.: High-resolution TEM studies of carbonization and graphitization, in: Chemistry and Physics of Carbon, edited by: Thrower, P. A., M. Dekker, New York, pp. 21-142, 1989.

Onischuk, A. A., di Stasio, S., Karasev, V. V., Baklanov, A. M., Makhov, G. A., Vlasenko, A. L., Sadykova, A. R., Shipovalov, A. 
V., and Panfilov, V. N.: Evolution of structure and charge of soot aggregates during and after formation in a propane/air diffusion flame, J. Aerosol Sci., 34, 383-403, 2003.

Patterson, E. M. and McMahon, C. K.: Absorption characteristics of forest fire particulate matter, Atmos. Environ., 18, 2541-2551, 1984.

Petzold, A., Kopp, C., and Niessner, R.: The dependence of the specific attenuation cross-section on black carbon mass fraction and particle size, Atmos. Environ., 31, 661-672, 1997.

Petzold, A. and Niessner, R.: Novel design of a resonant photoacoustic spectrophone for elemental carbon mass monitoring, Appl. Phys. Lett., 66, 1285-1287, 1995.

Petzold, A., Schloesser, H., Sheridan, P. J., Arnott, W. P., Ogren, J. A., and Virkkula, A.: Evaluation of multiangle absorption photometry for measuring aerosol light absorption, Aerosol Sci. Tech., 39, 40-51, 2005.

Petzold, A. and Schönlinner, M.: Multi-angle absorption photometry - a new method for the measurement of aerosol light absorption and atmospheric black carbon, J. Aerosol Sci., 35, 421-441, 2004.

Pöschl, U.: Aerosol particle analysis: challenges and progress, Anal. Bioanal. Chem., 375, 30-32, 2003.

Pósfai, M., Anderson, J. R., Buseck, P. R., and Sievering, H.: Soot and sulfate aerosol particles in the remote marine troposphere, J. Geophys. Res., 104, 21 685-21 693, 1999.

Ramanathan, V., Chung, C., Kim, D., Bettge, T., Buja, L., Kiehl, J. T., Washington, W. M., Fu, Q., Sikka, D. R., and Wild, M.: Atmospheric brown clouds: Impacts on South Asian climate and hydrological cycle, Proc. Natl. Acad. Sci. USA, 102, 5326-5333, 2005.

Redemann, J., Russell, P. B., and Hamill, P.: Dependence of aerosol light absorption and single-scattering albedo on ambient relative humidity for sulfate aerosols with black carbon cores, J. Geophys. Res., 106, 27 485-27 495, 2001.

Reid, J. S., Hobbs, P. V., Ferek, R. J., Blake, D. R., Martins, J. V., Dunlap, M. R., and Liousse, C.: Physical, chemical, and optical properties of regional hazes dominated by smoke in Brazil, J. Geophys. Res., 103, 32 059-32 080, 1998a.

Reid, J. S., Hobbs, P. V., Liousse, C., Martins, J. V., Weiss, R. E., and Eck, T. F.: Comparisons of techniques for measuring shortwave absorption and black carbon content of aerosols from biomass burning in Brazil, J. Geophys. Res., 103, 32 031-32 040, 1998b.

Reid, J. S., Koppmann, R., Eck, T. F., and Eleuterio, D. P.: A review of biomass burning emissions part II: intensive physical properties of biomass burning particles, Atmos. Chem. Phys., 5, 799825,2005 ,

http://www.atmos-chem-phys.net/5/799/2005/.

Rosen, H., Hansen, A. D. A., Gundel, L., and Novakov, T.: Identification of optically absorbing component in urban aerosols, Appl. Opt., 17, 3859-3861, 1978.

Rosen, H. and Novakov, T.: Raman-scattering and characterization of atmospheric aerosol particles, Nature, 266, 708-710, 1977.

Ruellan, S., Cachier, H., Gaudichet, A., Masclet, P., and Lacaux, J. P.: Airborne aerosols over central Africa during the experiment for regional sources and sinks of oxidants (EXPRESSO), J. Geophys. Res., 104, 30 673-30 690, 1999.

Sadezky, A., Muckenhuber, H., Grothe, H., Niessner, R., and Poeschl, U.: Raman micro spectroscopy of soot and related car- bonaceous materials: Spectral analysis and structural information, Carbon, 43, 1731-1742, 2005.

Schaap, M., Van Der Gon, H., Dentener, F. J., Visschedijk, A. J. H., Van Loon, M., ten Brink, H. M., Putaud, J. P., Guillaume, B., Liousse, C., and Builtjes, P. J. H.: Anthropogenic black carbon and fine aerosol distribution over Europe, J. Geophys. Res., 109, D18207, doi:10.1029/2003JD004330, 2004.

Schauer, J. J., Mader, B. T., Deminter, J. T., et al.: ACE-Asia intercomparison of a thermal-optical method for the determination of particle-phase organic and elemental carbon, Environ. Sci. Technol., 37, 993-1001, 2003.

Schmid, H., Laskus, L., Abraham, H. J., et al.: Results of the "carbon conference" international aerosol carbon round robin test stage I, Atmos. Environ., 35, 2111-2121, 2001.

Schmid, O., Artaxo, P., Arnott, W. P., Chand, D., Gatti, L. V., Frank, G. P., Hoffer, A., Schnaiter, M., and Andreae, M. O.: Spectral light absorption by ambient aerosols influenced by biomass burning in the Amazon Basin. I: Comparison and field calibration of absorption measurement techniques, Atmos. Chem. Phys. Discuss., 5, 9355-9404, 2005,

http://www.atmos-chem-phys-discuss.net/5/9355/2005/.

Schnaiter, M., Gimmler, M., Llamas, I., Linke, C., Jäger, C., and Mutschke, H.: Strong spectral dependence of light absorption by organic carbon particles formed by propane combustion, Atmos. Chem. Phys., 6, 2981-2990, 2006,

http://www.atmos-chem-phys.net/6/2981/2006/.

Schnaiter, M., Horvath, H., Möhler, O., Naumann, K. H., Saathoff, H., and Schöck, O. W.: UV-VIS-NIR spectral optical properties of soot and soot-containing aerosols, J. Aerosol Sci., 34, 14211444, 2003.

Schnaiter, M., Linke, C., Möhler, O., Naumann, K.-H., Saathoff, H., R. Wagner, and Schurath, U.: Absorption amplification of black carbon internally mixed with secondary organic aerosol, 110, D19204, doi:10.1029/2005JD006046, 2005 a.

Schnaiter, M., Schmid, O., Petzold, A., Fritzsche, L., Klein, K.-F., Andreae, M. O., Helas, G., Thielmann, A., Gimmler, M., Möhler, O., Linke, C., and Schurath, U.: Measurement of wavelengthresolved light absorption by aerosols utilizing a UV-VIS extinction cell, Aerosol Sci. Tech., 39, 249-260, 2005b.

Sharma, S., Brook, J. R., Cachier, H., Chow, J., Gaudenzi, A., and Lu, G.: Light absorption and thermal measurements of black carbon in different regions of Canada, J. Geophys. Res., 107, 4771, doi:10.1029/2002JD002496, 2002.

Sheridan, P. J., Arnott, W. P., Ogren, J. A., Andrews, E., Atkinson, D. B., Covert, D. S., Moosmüller, H., Petzold, A., Schmid, B., Strawa, A. W., Varma, R., and Virkkula, A.: The Reno Aerosol Optics Study: An evaluation of aerosol absorption measurement methods, Aerosol Sci. Tech., 39, 1-16, 2005.

Smith, F. W.: Optical constants of a hydrogenated amorphous carbon film, J. Appl. Phys., 55, 764-771, 1984.

Streets, D. G., Gupta, S., Waldhoff, S. T., Wang, M. Q., Bond, T. C., and Yiyun, B.: Black carbon emissions in China, Atmos. Environ., 35, 4281-4296, 2001.

Su, D. S., Müller, J. O., Jentoft, R. E., Rothe, D., Jacob, E., and Schlögl, R.: Fullerene-like soot from EuroIV diesel engine: consequences for catalytic automotive pollution control, Topics in Catalysis, 30-31, 241-245, 2004.

Sze, S. K., Siddique, N., Sloan, J. J., and Escribano, R.: Raman spectroscopic characterization of carbonaceous aerosols, Atmos. 
Environ., 35, 561-568, 2001.

ten Brink, H., Maenhaut, W., Hitzenberger, R., Gnauk, T., Spindler, G., Even, A., Chi, X. G., Bauer, H., Puxbaum, H., Putaud, J. P., Tursic, J., and Berner, A.: INTERCOMP2000: the comparability of methods in use in Europe for measuring the carbon content of aerosol, Atmos. Environ., 38, 6507-6519, 2004.

Truex, T. J. and Anderson, J. E.: Mass monitoring of carbonaceous aerosols with a spectrophone, Atmos. Environ., 13, 507-509, 1979.

Turner, J. and Hering, S.: The additivity and stability of carbon signatures obtained by eveolved gas analysis, Aerosol Sci. Tech., 21, 294-305, 1994.

Wang, C.: A modeling study on the climate impacts of black carbon aerosols, J. Geophys. Res., 109, D03106, doi:10.1029/2003JD004084, 2004.

Watson, J. G., Chow, J. C., and Chen, L.-W. A.: Summary of organic and elemental carbon/black carbon analysis methods and ntercomparisons, Aerosol and Air Quality Research, 5, 65-102, 2005.

Weingartner, E., Burtscher, H., and Baltensperger, U.: Hygroscopic properties of carbon and diesel soot particles, Atmos. Environ., 31, 2311-2327, 1997.

Weingartner, E., Saathoff, H., Schnaiter, M., Streit, N., Bitnar, B., and Baltensperger, U.: Absorption of light by soot particles: determination of the absorption coefficient by means of aethalometers, J. Aerosol Sci., 34, 1445-1463, 2003.

Wentzel, M., Gorzawski, H., Naumann, K. H., Saathoff, H., and Weinbruch, S.: Transmission electron microscopical and aerosol dynamical characterization of soot aerosols, J. Aerosol Sci., 34, 1347-1370, 2003.
White, A. H. and Germer, L. H.: The structure of black carbon, J. Chem. Phys., 9, 492-502, 1941.

Wittmaack, K.: Characterization of carbon nanoparticles in ambient aerosols by scanning electron microscopy and model calculations, J. Air \& Waste Manage. Assoc., 54, 1091-1098, 2004.

Wittmaack, K.: Combustion characteristics of water-insoluble elemental and organic carbon in size selected ambient aerosol particles, Atmos. Chem. Phys., 5, 1905-1913, 2005, http://www.atmos-chem-phys.net/5/1905/2005/.

Yasa, Z., Amer, N. M., Rosen, H., Hansen, A. D. A., and Novakov, T.: Photoacoustic investigation of urban aerosol particles, Appl. Opt., 18, 2528-2530, 1979.

Yu, J. Z., Xu, J. H., and Yang, H.: Charring characteristics of atmospheric organic particulate matter in thermal analysis, Environ. Sci. Technol., 36, 754-761, 2002.

Yu, J. Z., Yang, H., Zhang, H. Y., and Lau, A. K. H.: Size distributions of water-soluble organic carbon in ambient aerosols and its size-resolved thermal characteristics, Atmos. Environ., 38, 1061-1071, 2004.

Zappoli, S., Andracchio, A., Fuzzi, S., Facchini, M. C., Gelencsér, A., Kiss, G., Krivácsy, Z., Molnár, A., Mészáros, E., Hansson, H.-C., Rosman, K., and Zebühr, Y.: Inorganic, organic and macromolecular components of fine aerosol in different areas of Europe in relation to their water solubility, Atmos. Environ., 33, 2733-2743, 1999. 